\title{
Productive T-cell receptor $\beta$-chain gene rearrangement: coincident regulation of cell cycle and clonality during development in vivo
}

\author{
Eric S. Hoffman, ${ }^{1,2,8}$ Lorena Passoni, ${ }^{1,8}$ Tessa Crompton, ${ }^{4}$ Thomas M.J. Leu, ${ }^{5}$ David G. Schatz, ${ }^{2,3}$ \\ Andrew Koff, ${ }^{6}$ Michael J. Owen, ${ }^{4}$ and Adrian C. Hayday ${ }^{1,2,7}$ \\ ${ }^{1}$ Department of Biology and ${ }^{2}$ Section of Immunobiology and ${ }^{3}$ Howard Hughes Medical Institute, Yale University, New \\ Haven, Connecticut 06510 USA; $^{4}$ Imperial Cancer Research Fund Laboratories, London WC2 3PX, UK; ${ }^{5}$ Universität \\ Zürich-Irchel, Veterinärbiochemie, 8057 Zürich, Switzerland; 'Program in Molecular Biology, Memorial Sloan-Kettering \\ Cancer Center, New York, New York 10021 USA
}

\begin{abstract}
Productive gene rearrangement at the T-cell receptor (TCR) $\beta$-chain locus facilitates formation of the "pre-TCR," a molecular complex that is important for the subsequent development of $\alpha \beta \mathrm{T}$ cells. The transition of thymocytes from a population of cells undergoing TCR $\beta$ chain genes to a population enriched in cells with productively rearranged TCR $\beta$ chain genes is known as " $\beta$ selection." This is the first point in $\alpha \beta$ T-cell development at which the products of an activated TCR locus define cell phenotype. Toward an understanding of these events, this study has focused on a set of thymocytes defined by cell surface phenotype as $\mathrm{HSA}^{+} \mathrm{CD}_{4}{ }^{\text {low }} \mathrm{CD} 25^{+}$, in which the bulk of TCR $\beta$ gene rearrangement occurs. The analysis of this set, presented here, allows its novel subdivision into two subsets that are respectively strong candidates for cells immediately prior to and immediately following TCR $\beta$ selection. Cells that have passed $\beta$ selection differ from the preceding cells by several criteria, including hyperphosphorylation of $\mathbf{R b}$, increased expression of cyclins $A$ and $B$, down-regulation of p27, increased CDK2 activity, an induction of cdc2 activity, and progression through DNA synthesis. Consistent with these changes being attributable to productive TCR $\beta$ chain gene rearrangement, the identified " $\beta$-selected" subset is not detected in mutant mice that cannot assemble a pre-TCR. Interestingly, there is a coincident selective and transient down-regulation of the protein RAG2, on which TCR gene rearrangement obligatorily depends. Together, these findings demonstrate that productive TCR gene rearrangement is associated with events that can ensure thymocyte expansion and monoclonality.
\end{abstract}

[Key Words: Pre-T-cell receptor; thymocytes; RAG2; cell cycle; immune system development]

Received November 27, 1995; revised version accepted February 28, 1996.

$\mathrm{T}$ cells develop from progenitors that enter the thymus expressing very low levels of CD4, which they soon lose,

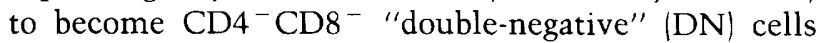
(Wu et al. 1991) that comprise $1 \%-2 \%$ of thymocytes. The DN cells proceed through a series of differentiation stages (defined by distinct cell surface phenotypes), until they acquire CD4 and CD8, becoming "double-positive" (DP) cells, essentially all of which have successfully rearranged genes at the T-cell receptor $\beta$ (TCR $\beta$ ) chain locus (Mallick et al. 1993). Contingent upon successful rearrangement of a T-cell receptor $\alpha(\mathrm{TCR} \alpha)$ chain gene, DP cells lose either CD4 or CD8, becoming mature "sin-

\footnotetext{
${ }^{7}$ Corresponding author.

Present address: Kline Biology Tower, 266 Whitney Ave., New Haven,

Connecticut 06510 USA.

${ }^{8}$ The first two authors contributed equally to this study.
}

gle-positive" (SP) cells that exit to the periphery /Scollay and Shortman 1985; Petrie et al. 1990; Rothenberg et al. 19921.

The productive rearrangement of a TCR $\beta$ chain gene by $\mathrm{DN}$ thymocytes is a critical mechanistic stage in T-cell development (Mombaerts et al. 1992b; Mallick et al. 1993; Shinkai et al. 1993; Dudley et al. 1994; Godfrey et al. 1994). The product of the TCR $\beta$ chain gene is complexed with a $33-\mathrm{kD}$ surrogate TCR $\alpha$ chain gene /Groettrup et al. 1993), named pre-T $\alpha$, to form a "pre-TCR" (Saint-Ruf et al. 1994). Cells that do not express the preTCR are, to a first approximation, blocked in their capacity either to proliferate or to differentiate further (Fehling et al. 1995), whereas cells that productively rearrange the TCR $\beta$ chain genes progress to the DP stage. This is termed " $\beta$ selection." A highly analogous checkpoint exists in B-cell development, regulated by a pre-B- 
cell receptor comprising the product of a successful immunoglobulin heavy-chain gene rearrangement, combined with a surrogate light-chain, $\lambda 5 /$ VpreB (Kitamura et al. 1992).

Although the formation and expression of pre-antigen receptors is thus a critical event in lymphocyte development, events associated with preantigen receptor expression are currently poorly understood. Prior to $\beta$ selection, cells are in a stage defined by cell surface markers as $\mathrm{HSA}^{\text {hi }} \mathrm{CD} 4^{-} \mathrm{CD} 8^{-} \mathrm{CD} 44^{\text {low }} \mathrm{CD} 25^{+}$(or, for the purposes of this paper, $\mathrm{CD} 25^{+}$, for short). $\beta$ Selection facilitates transition to a stage defined as $\mathrm{HSA}^{\text {hi }} \mathrm{CD} 4^{-} \mathrm{CD} 8^{-}$ $\mathrm{CD} 44^{\text {low }} \mathrm{CD} 25^{-}$(or $\mathrm{CD} 25^{-}$, for short). Thus, normal numbers of CD25- cells do not form in TCR $\beta-/-$ mice (Mombaerts et al. 1992b), preT $\alpha-/-$ mice (Fehling et al. 1995), or recombinase activating gene (RAG)1 or RAG2 - / - mice (Mombaerts et al. 1992a; Shinkai et al. 1992) (both RAG proteins being essential for TCR gene rearrangement and hence for expression of the pre-TCR/. Most $\mathrm{CD} 25^{+}$cells have been reported to have $2 \mathrm{~N}$ DNA content, typical of resting cells or cycling cells in $\mathrm{G}_{1}$. A much higher proportion of $\mathrm{CD} 25^{-}$cells has been reported to be in S phase (Pearse et al. 1989). Thus, it has been hypothesized that $\beta$ selection immediately promotes a cell cycle transition, preferentially expanding the pool of precursors deemed useful by virtue of successful TCR $\beta$ chain gene rearrangement (Dudley et al. 1994).

At the same time, a central tenet of immunology is lymphocyte clonality. Over $90 \%$ of peripheral $\mathrm{T}$ cells express only a single, productively rearranged $\beta$ chain gene, as a result of "allelic exclusion," the mechanism by which expression of an immunoglobulin or TCR chain (in this case, a TCR $\beta$ chain) inhibits further rearrangement at the second allele of the corresponding lo- cus (Mallisen et al. 1992; Robey and Fowlkes 1994). Interestingly, the capacity of productive TCR $\beta$ chain gene to inhibit further rearrangement may, in part, be related to its above-mentioned putative capacity to promote cell cycle transition. This is because RAG2 protein is rendered 20 -fold less stable in vitro by the action of cdc2 (Lin and Desiderio 1993, 1995), a kinase associated with progression of mammalian cells into $\mathrm{G}_{2} / \mathrm{M}$.

To investigate the plausibility of this scenario in vivo, we have examined thymocytes actively engaged in TCR $\beta$ chain gene rearrangement. The studies have facilitated redefinition of the stage in thymocyte development at which $\beta$ selection occurs, indicating that it is tightly associated with the movement of cells from a $G_{1}$ state to an active cycling state, in which the RAG2 protein is selectively and transiently down-regulated.

\section{Results}

Thymocyte subset purification

Developing thymocytes on either side of the pre-TCRmediated transition were purified by fluorescence-activated cell sorting (FACS) based on surface marker expression (Fig. 1). A typical experiment began with $10 \mathrm{C} 57 . \mathrm{BL} /$ 6J female mice at 3-4 weeks of age. From these, $3 \times 10^{9}$ thymocytes were harvested. After complement depletion of $\mathrm{CD}^{+}{ }^{+}$and $\mathrm{CD} 8{ }^{+}$cells, $5 \times 10^{7}$ thymocytes $(1.7 \%)$ were recovered that were $\mathrm{CD} 8^{-}$and largely $\mathrm{CD} 4^{-}$(data not shown). Subsequent sorting eliminated remaining $\mathrm{CD} 4^{\text {dull }}$ cells and facilitated recovery of $3 \times 10^{6} \mathrm{CD}^{-}$ $\mathrm{HSA}^{+} \mathrm{CD}^{+} 4^{\text {low }} \mathrm{CD}_{25} 5^{+}\left(\mathrm{CD} 25^{+}\right)$cells $(0.1 \%)$ and $2.5 \times 10^{6} \mathrm{CD}^{-} \mathrm{HSA}^{+} \mathrm{CD} 44^{\text {low }} \mathrm{CD} 25^{-}\left(\mathrm{CD} 25^{-}\right)$cells $(0.08 \%)$ per sort (Wilson et al. 1988; Dudley et al. 1994). Purity was consistently $>98 \%$. We have shown previ-

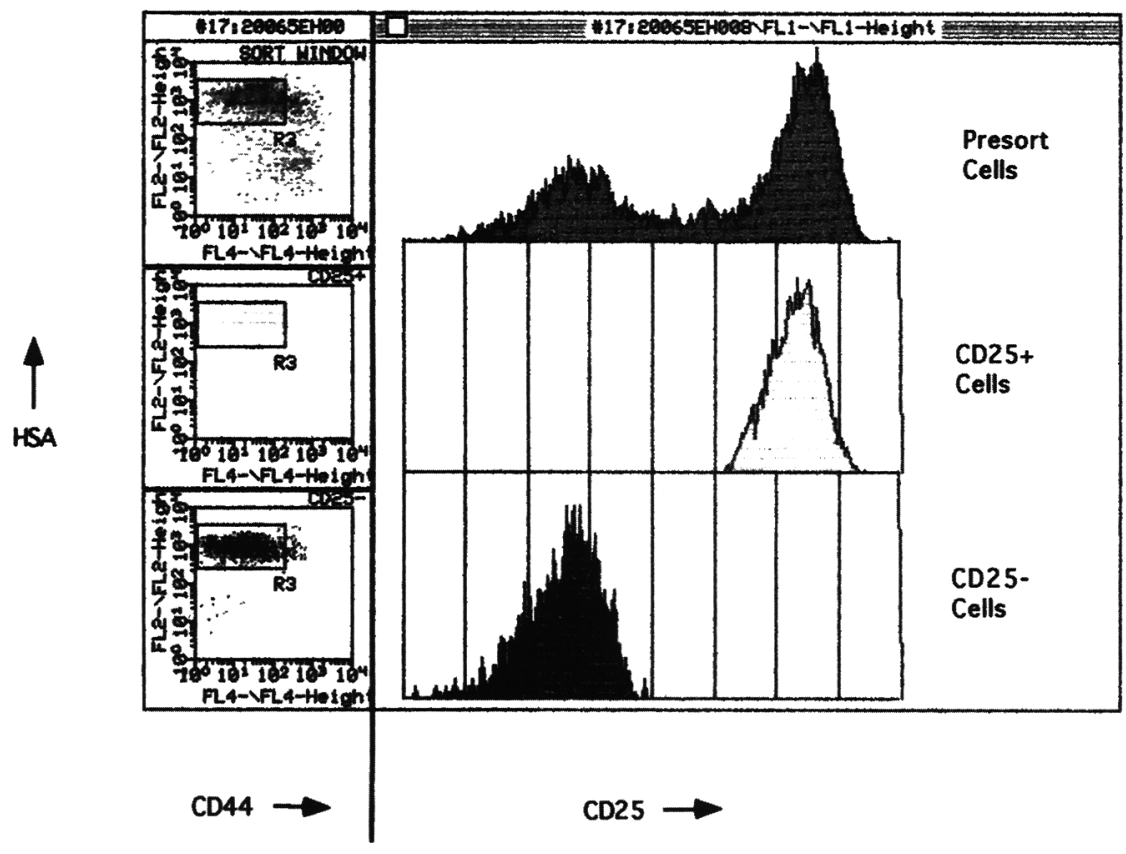

Figure 1. Purification of thymocyte subsets by FACS sorting. Normal mouse thymocytes were complement-depleted of $\mathrm{CD} 4^{+}$ and $\mathrm{CD} 8{ }^{+}$cells and stained with a panel of fluorescent antibodies. (Top) Presorted cells were separated based on $\mathrm{HSA}^{+} \mathrm{CD} 44^{\text {low }}$ $\mathrm{CD} 25^{+}$or $\mathrm{CD}_{25}$ expression; (middle) $\mathrm{CD}_{25}{ }^{+}$cells after sorting; (bottom) $\mathrm{CD} 25^{-}$ cells after sorting were reanalyzed for surface marker expression. Thymocytes were also sorted only for $\mathrm{CD}^{-}$cells (see text; data not shown). 
ously that $\mathrm{CD} 25^{+}$cells purified in this way are largely in the process of rearranging their TCR $\beta$ chain genes, whereas $\mathrm{CD} 25^{-}$cells purified in this way have essentially all passed $\beta$ selection (Dudley et al. 1994). As a first test of the cell cycle status of the two subsets, their respective DNA contents were examined. In this, as in all assays described below, comparison was made between $\mathrm{CD} 25^{+}$and $\mathrm{CD} 25^{-}$cells harvested at the same time as each other.

\section{DNA content analysis of $\mathrm{CD}_{2} 5^{+}$and $\mathrm{CD} 25^{-}$cells}

It was reported previously by several investigators that $\mathrm{CD} 25^{+}$cells are largely resting cells, mostly with $2 \mathrm{~N}$ DNA content, whereas many CD25- cells are proliferating, with $>2 \mathrm{~N}$ DNA (Pearse et al. 1989; Penit et al. 1995). This was confirmed using propidium iodide staining of DNA and FACS analysis, with a doublet discrimination function to ensure that only single cells were analyzed. $\mathrm{CD} 25^{+}$cells typically included $\sim 8 \%-10 \%$ cells in $\mathrm{S} / \mathrm{G}_{2} / \mathrm{M}$ (Fig. $2 \mathrm{~A}$ ), whereas $\mathrm{CD} 25^{-}$cells typically demonstrated $\sim 24 \%$ cells in $S / G_{2} / M$ (Fig. $2 B$ ). To test whether cells prior to $\beta$ selection were blocked in the cell cycle, analysis was made of $\mathrm{CD} 25^{+}$cells from TCR $\beta \times \delta$-deficient mice, unable to express the products of in-frame TCR $\beta$ rearrangements. These cells typically displayed only a background level of cells in $S / G_{2} / M$ (Fig. 2C). Taken together, the data suggest that most, if not all, $\mathrm{CD} 25^{+}$cells from normal mice that are in $S / G_{2} / M$ were induced to leave $G_{1}$ because of productive TCR gene rearrangement. This, in turn, suggests that the pre-TCR signal occurs within the $\mathrm{CD} 25^{+}$subset, inducing a cell cycle progression before CD25 surface expression is lost. To test this, the CD $25^{+}$cells were separated into two distinct subsets for further analysis.

\section{DNA content analysis of subsets of $\mathrm{CD}^{2} 5^{+}$cells}

Progression through $G_{1}$ and into $S / G_{2} / M$ phase often correlates with an increase in cell size. By confocal microscopy (see below), most CD25 ${ }^{+}$cells were sized between 6.5 and $8.5 \mu \mathrm{m}$, an "expected" result based on previous studies (Godfrey et al. 1994; Penit et al. 1995), whereas between $10 \%$ and $15 \%$ of cells were $>8.5 \mu \mathrm{m}$, commonly $\sim 10.5 \mu \mathrm{m}$ (Table 1 ). In contrast, $\mathrm{CD} 25^{+}$cells from TCR $\beta \times \delta$-deficient mice were homogeneous, with $<1 \%$ of cells $>8.5 \mu \mathrm{m}$ (Table 1). The larger $15 \%$ of $\mathrm{CD} 25^{+}$cells from normal mice could be separated from other $\mathrm{CD} 25^{+}$cells by forward and side scatter (Fig. 2D), whereas, predicatably, the larger subset was essentially absent in $\mathrm{CD} 25^{+}$cells from either TCR $\beta \times \delta$-deficient mice (Fig. 2E) or RAG2-deficient mice (Fig. 2F). The cells of expected size, hereafter termed subset $\mathrm{E}$, showed only background levels of cells in $S / G_{2} / M$ (Fig. $2 G$ ), indistinguishable from $\mathrm{CD} 25^{+}$cells from TCR $\beta \times \delta$-deficient mice (Fig. 2C). Conversely, the larger $\mathrm{CD} 25^{+}$cells, hereafter termed the "L subset," featured $\sim 66 \%$ of cells in $\mathrm{S} / \mathrm{G}_{2} / \mathrm{M}$ (Fig. $2 \mathrm{H}$ ). This is consistent with $8 \%-10 \%$ of bulk CD $25^{+}$cells being in $\mathrm{S} / \mathrm{G}_{2} / \mathrm{M}(66 \%$ of $15 \%)$. Thus, subset $\mathrm{L}$ describes $\mathrm{CD} 25^{+}$cells that are largely in $S / G_{2} / M$ and that are essentially absent from mutant mice that for a variety of congenital faults cannot assemble a TCR $\beta|+|$ pre-TCR. The prediction would therefore be that $L$ cells should show evidence of $\beta$ selection.

\section{PCR-RFLP analysis of TCR $\beta$ chain joins}

To test that the $\mathrm{CD} 25^{+} \mathrm{L}$ subset had passed through $\beta$ selection, a polymerase chain reaction-restriction fragment length polymorphism (PCR-RFLP) analysis of TCR $\beta$ chain gene rearrangements was undertaken as described previously (Mallick et al. 1993; Dudley et al. 1994). By revealing the status of TCR gene rearrangements in a polyclonal population of cells, PCR-RFLP allows rapid elucidation of whether or not cells in a population have apparently been selected for on the basis of in-frame and, therefore, productive TCR gene rearrangements.

TCR $V \beta 4-J \beta 2.2$ and $V \beta 5-/ \beta 2.2$ rearrangements were examined from $\mathrm{CD} 25^{+}$subsets $\mathrm{E}$ and $\mathrm{L}$ (Fig. 3). $V(D)$ I joining fragments from $\mathrm{CD} 25^{+} \mathrm{E}$ cells (the majority subset) showed no enrichment for productive rearrangements [that would have been evident in a repeating pattern of bands of periodicity 3 nucleotides (Mallick et al. 1993; Dudley et al. 1994)]. Instead, the sequence lengths of the bands were close to random, with some depletion of in-frame rearrangements (E lanes), consistent with the analysis of $\mathrm{CD} 25^{+}$cells as a whole (Dudley et al. 1994). In contrast, joins from CD25 ${ }^{+} \mathrm{L}$ cells showed a predominantly in-frame triplet periodicity (L lanes), indicating that $\beta$ selection had occurred prior to formation of the $\mathrm{CD} 25^{+} \mathrm{L}$ cell subset.

This improved definition of the point of $\beta$ selection is illustrated in Figure 4. Although it might be argued that no formal demonstration has been made of a precursorproduct relationship between $\mathrm{E}$ and $\mathrm{L}$, this is the most likely explanation given that significant TCR $\beta$ chain gene rearrangement does not appear to commence until the CD25+ stage (Godfrey et al. 1994) and that in mice of various genotypes that cannot successfully express the

Figure 2. DNA content analysis of thymocyte subsets by propidium iodide staining. CD25 $5^{+}$cells from normal mice $(A), \mathrm{CD} 25^{-}$cells from normal mice $(B)$, and $C D 25^{+}$cells from TCR $\beta \times \delta$-deficient mice $(C)$ were stained for DNA content with propidium iodide and analyzed by FACS. Percentages of cells in $G_{0} / G_{1}$ and $S / G_{2} / M$ are indicated. Doublet discrimination ensured that only single cells were counted. $(D) \mathrm{CD} 25^{+}$cells from normal mice were FACS-sorted by cell size /sorting gates: $\mathrm{E}=$ the bulk of the cells of expected size; $\mathrm{L}=$ larger cells) based on forward and side scatter. Percentages of cells in the E and L gates are indicated. CD25 $5^{+}$cells from TCR $\beta \times \delta$ deficient mice $(E)$ and RAG2-deficient mice $|F|$ were shown to have minimal numbers of $L$ cells based on the same forward and side scatter settings. After sorting, CD $25^{+}$E cells $(G)$ and $\mathrm{CD} 25^{+} \mathrm{L}$ cells $(H)$ from normal mice were analyzed for DNA content by propidium iodide staining. 

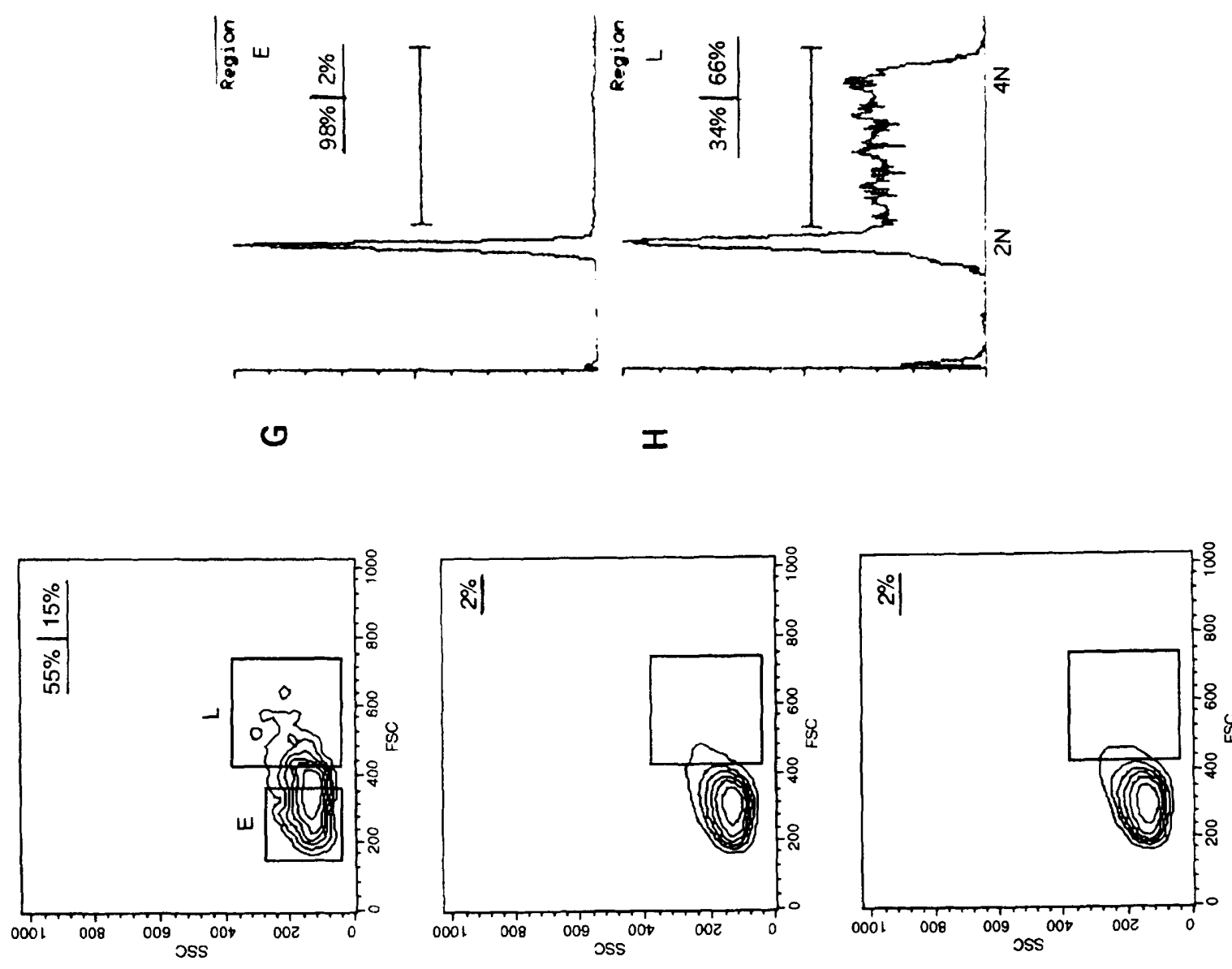

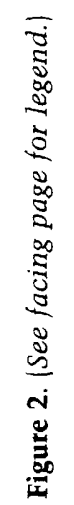
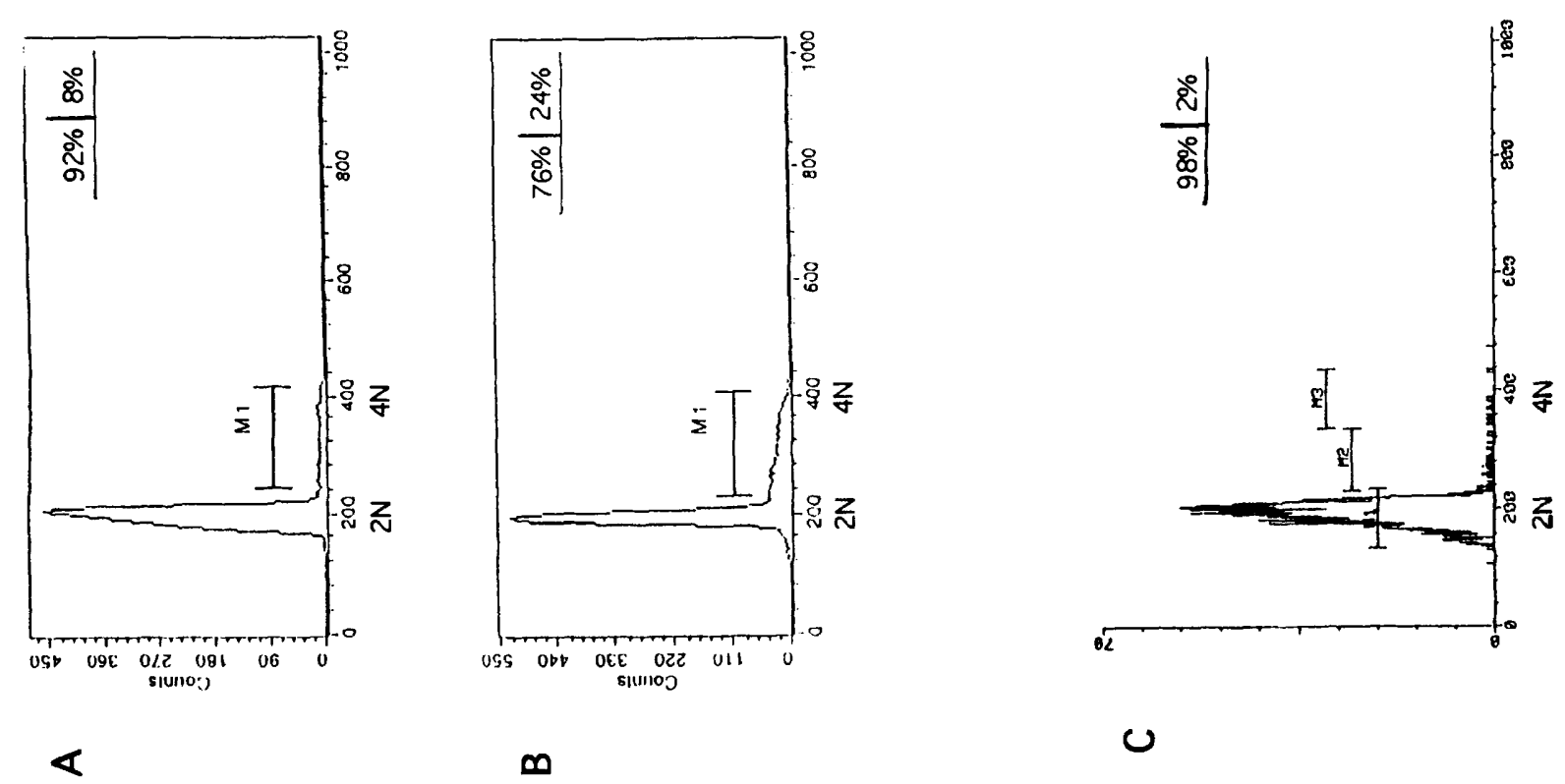
Table 1. CD44 ${ }^{\text {low }} \mathrm{CD} 25^{+}$thymocyte size distribution from normal and TCR-deficient mice measured by confocal microscopy

\begin{tabular}{|c|c|c|}
\hline \multirow[b]{2}{*}{ Mouse strain } & \multicolumn{2}{|c|}{$\mathrm{CD} 44^{\text {low }} \mathrm{CD} 25^{+}$thymocyte size } \\
\hline & $\begin{array}{c}\leqslant 8.5 \mu \mathrm{m} \\
\text { (expected) }\end{array}$ & $\begin{array}{c}>8.5 \mu \mathrm{m} \\
\quad \text { (larger) }\end{array}$ \\
\hline C57.BL /6 (normal) & $85.6 \%$ & $14.4 \%$ \\
\hline TCR deficient $\{\beta$ and $\delta\}$ & $99.0 \%$ & $0.97 \%$ \\
\hline
\end{tabular}

pre-TCR, thymocyte development is largely arrested at the CD25 ${ }^{+}$stage (Mombaerts et al. 1992a; Shinkai et al. 1992; Fehling et al. 1995). Therefore, $\mathrm{CD} 25^{+} \mathrm{E}$ and $\mathrm{CD} 25^{+} \mathrm{L}$ subsets are good candidates for cells cither side of TCR $\beta$ selection, and their characterization is thus an important step toward understanding events that follow productive TCR $\beta$ chain gene rearrangement.

\section{Confocal microscopy analysis of thymocytes for cell cycle regulators}

The progression of mammalian cells through the cell cycle is regulated in large part by the expression of cyclins, which activate cyclin-dependent kinases (CDKs). In asynchronously growing cultures of cells, CDK levels remain relatively constant throughout the cell cycle, whereas the levels of most cyclins vary dramatically. Expression of D-type cyclins (e.g., D2, D3), which activate CDK6, generally indicates that cells are in the mitotic cycle rather than in $\mathrm{G}_{0}$; high expression of cyclin $\mathrm{E}$, which activates $\mathrm{CDK} 2$, indicates that cells are progressing through mid-late $G_{1}$; high expression of cyclin $A$, which also activates $\mathrm{CDK} 2$, indicates that cells have progressed into and beyond the late $\mathrm{G}_{1}$; and high expression of cyclin B indicates that cells have progressed into and past the middle of S phase (Koff et al. 1992; Ohtsubo and Roberts 1993). Superimposed upon periodic cyclin-dependent activation of CDKs is the capacity of other proteins, CDK inhibitors (CDIs), to inhibit CDK activity despite the presence of the requisite cyclin. Thus, CDI p27 can inhibit CDK2-cyclin A/E and, thereby, the progression of cells into $S$ phase (Polyak et al. 1994a,b; Sherr and Roberts 1995).

$\mathrm{CD} 25^{+}$cells were analyzed for the expression of cell cycle-associated proteins by immunofluorescent confocal microscopy. In each case, a cell cycle protein antibody was followed by a Lissamine rhodamine-conjugated secondary antibody, visualized as red staining. CD $25^{+}$ cells retain the fluorescein isothiocyanate (FITC)-conjugated anti-CD25 antibody staining used in the sorting, which appears as a green ring around the cells' perimeters. Compared with the negative control (Fig. 5A), in which cells were treated with the Lissamine rhodamineconjugated secondary antibody without prior reaction with an antibody against a cell cycle protein, positive (red) staining for cyclins D2 and D3 was detected in all CD $25^{+}$cells (Fig. 5B,C). Superposition of cyclin and CD25 staining sometimes resulted in yellow staining, an example of which is shown in Figure 5B. Cyclin D2 was reproducibly the weaker of the two D cyclins expressed. (Cyclin D1 was not detected in CD25 cells, as is the case in other studies of lymphocytes.) Compared with the negative control of a field of cells (Fig. 5D), CD25 cells were homogeneously positive for cyclin $\mathrm{E}$ (Fig. 5E). In contrast, a heterogeneity in $\mathrm{CD} 25^{+}$cells was apparent for cyclin A: Whereas most cells were weakly positive for cyclin A (Fig. 5F), a few $\mathrm{CD} 25^{+}$cells were strongly stained (e.g., arrow in Fig. 5F). Conversely, a few CD $25^{+}$ cells stained less strongly than most for $\mathrm{p} 27$, an inhibitor of $\mathrm{G}_{1}$ CDKs (Fig. 5G, arrow). Likewise, whereas most $\mathrm{CD} 25^{+}$cells expressed very little cyclin B, mostly in a punctate pattern underlying the membrane, $\sim 10 \%$ of $\mathrm{CD} 25^{-}$cells expressed higher levels of cyclin B (data not shownl. Thus, as for DNA content (Fig. 2) and for TCR $\beta$ chain gene rearrangement (Fig. 3), CD2 $5^{+}$cells fell into two subsets according to the expression of cell cycleassociated proteins.

To determine whether cell size was also a good correlate of differential cyclin-A and p27 expression, cells of diameter $<8.5 \mu \mathrm{m}$ (the $\mathrm{E}$ subset) and cells of diameter $\leqslant 8.5 \mu \mathrm{m}$ (the L subset) were assayed independently for p27 and cyclin-A staining. This analysis showed that in the $\mathrm{E}$ subset $>91 \%$ of cells were strongly positive for $\mathrm{p} 27$ and $>95 \%$ were only weakly positive for cyclin A (Table $2 \mathrm{~A}$ ). In contrast, in the $\mathrm{L}$ subset, $>90 \%$ of cells were only weakly positive for $\mathrm{p} 27$, whereas $>75 \%$ were strongly positive for cyclin A. Likewise, when the reciprocal assay was performed, first assessing cyclin-A and p27 expression and then independently measuring cell size, $\sim 95 \%$ of cells only weakly positive for cyclin A and $\sim 97 \%$ of cells strongly positive for p 27 were $<8.5 \mu \mathrm{m}$ (E subset) (Table 2B). Together, these data indicate that subdivision of $\mathrm{CD} 25^{+}$cells into $\mathrm{E}$ and $\mathrm{L}$ subsets according to size operationally defines two cell phenotypes: One sub-

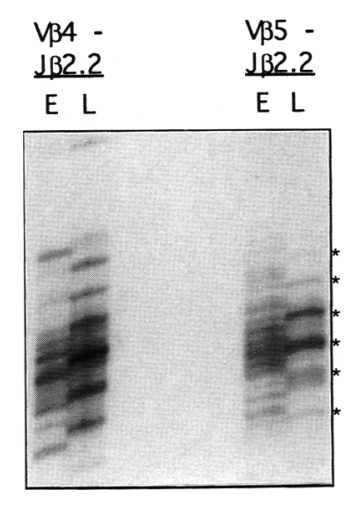

Figure 3. $V \beta$ to J $\beta$ PCR-RFLP. Analysis of TCR $V \beta$ to $/ \beta$ joins from CD25- $\mathrm{E}$ and $\mathrm{CD} 25^{\circ} \mathrm{L}$ cells by PCR-RFLP. (Lane $1, \mathrm{E}$ ) $V \beta 4$ to $/ \beta 2.2$ joins from $C D 25^{-}$E cells; (lane $2, L$ ) $V \beta 4$ to $/ \beta 2.2$ joins from $\mathrm{CD} 25^{\circ} \mathrm{L}$ cells, amplified by $\mathrm{PCR}$ and size-determined by comparison to a sequencing gel of known sizes. (Lane $7, \mathrm{E}) V / \beta 5$ to $/ \beta 2.2$ joins from CD25 ${ }^{+}$E cells; (lane $8, L$ ) V 35 to $J \beta 2.2$ joins from $\mathrm{CD} 25^{+} \mathrm{L}$ cells were likewise analyzed. Asterisks denote sizes equivalent to in-frame gene rearrangements. 


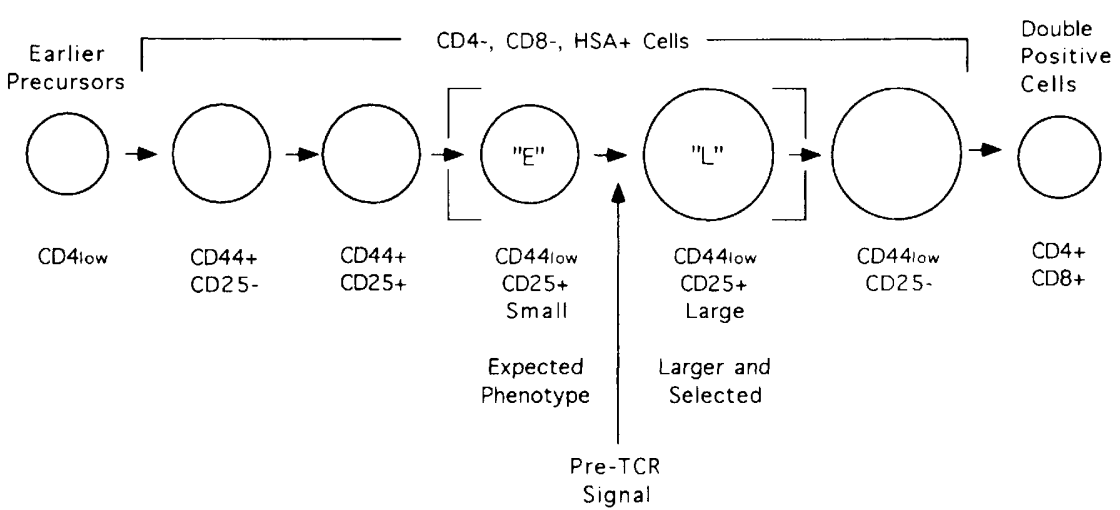

Figure 4. A revised model of postnatal thymoctyte developmental sequence. $\beta$ Selection occurs within the $\mathrm{CD} 4^{-} \mathrm{CD} 8^{-}$ $\mathrm{HSA}^{+} \mathrm{CD} 44^{\text {low }} \mathrm{CD} 25^{+}$thymocyte population, signaling the transition to the larger $\mathrm{L}$ cells. set has $2 \mathrm{~N}$ DNA, expresses high levels of cyclin $E$ and p27, expresses low levels of cyclin A, and displays essentially random rearrangements of TCR $\beta$ chain genes; the other subset commonly contains $>2 \mathrm{~N}$ DNA, expresses high levels of cyclin $E$ and cyclin A, expresses low levels of $\mathrm{p} 27$, and displays predominantly in-frame TCR $\beta$ chain gene rearrangements. Consistent with this, only 2 of 110 $\mathrm{CD} 25^{+}$cells from TCR $\beta \times \delta$-deficient land thus, preTCR-deficient) mice were clearly positive for cyclin A (Table $2 \mathrm{C}$ ). That is, the CD25+ $\mathrm{E}$ subset of normal mice appears similar to all $\mathrm{CD}^{2} 5^{+}$cells in TCR $\beta \times \delta$-deficient mice.

\section{Cell cycle protein analysis by Western blot}

To confirm and extend the staining data, the expression of several cell cycle proteins was examined by Western blotting of lysates of total CD $25^{+}$cells, CD25 ${ }^{+}$E cells, $\mathrm{CD} 25^{+} \mathrm{L}$ cells, and $\mathrm{CD} 25^{-}$cells. Consistent with the confocal data, $60-\mathrm{kD}$ cyclin A was barely detectable in the $\mathrm{CD} 25^{+}$E subset (Fig. 6A, lane E) but was clearly present both in the $\mathrm{CD} 25^{+} \mathrm{L}$ subset (Fig. 6A, lane $\mathrm{L}$ ) and in CD25- cells (Fig. 6A, CD $44^{\text {low }} / \mathrm{CD} 25^{-}$). The cyclin A detectable in unfractionated $\mathrm{CD} 25^{+}$cells (Fig. 6A, $\mathrm{CD} 44^{\mathrm{low}} / \mathrm{CD} 25^{+}$| can therefore be largely attributed to
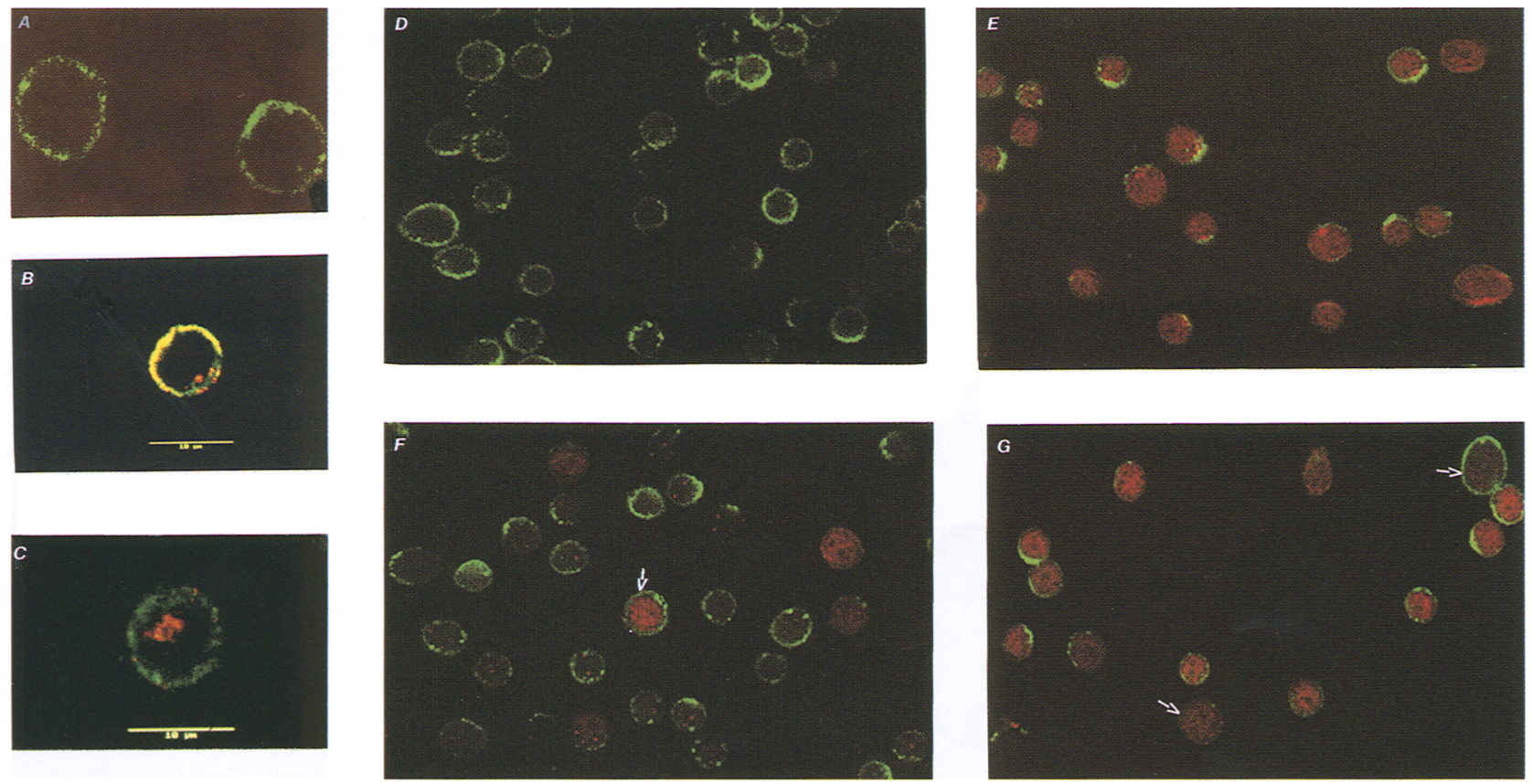

Figure 5. Confocal immunofluorescence analysis of cell cycle proteins. CD25 thymocytes from normal mice were stained with one of several antibodies specific for cell cycle proteins followed by a secondary antibody conjugated to Lissamine rhodamine, which is visualized as red staining. CD25 $5^{+}$cells retain the FITC-conjugated anti-CD25 antibody staining used in the sorting, which appears as a green ring around the perimeters of the cells. $(A, D)$ Secondary antibody alone shows only the CD25 ring; $(B)$ antibody specific for cyclin D2; $(C)$ antibody specific for cyclin $\mathrm{D} 3 ;(E)$ antibody specific for cyclin $\mathrm{E} ;(F)$ antibody specific for cyclin $\mathrm{A}_{;}(G) \mathrm{B}$ antibody specific for $\mathrm{p} 27$. 
Table 2. Cyclin $A$ and $p 27$ have differential expression patterns in $C D 44^{\text {low }} \mathrm{CD} 25^{+} \mathrm{E}$ and $\mathrm{CD} 44^{\text {low }} \mathrm{CD} 25^{+} \mathrm{L}$ thymocytes by confocal immunofluorescence microscopy

A. Protein expression based on cell size

Protein and expression level

\begin{tabular}{|c|c|c|c|c|}
\hline \multirow{3}{*}{$\begin{array}{l}\mathrm{CD} 44^{\text {low }} \mathrm{CD} 25^{+} \\
\text {cell diameter }\end{array}$} & \multirow{2}{*}{\multicolumn{2}{|c|}{ cyclin A level }} & & \\
\hline & & & \multicolumn{2}{|c|}{ p27 level } \\
\hline & low & high & low & high \\
\hline $\begin{array}{l}<8.5 \mu \mathrm{m} \\
\quad \text { (expected) }\end{array}$ & $95.2 \%$ & $4.8 \%$ & $8.6 \%$ & $91.4 \%$ \\
\hline $\begin{aligned} \geqslant & 8.5 \mu \mathrm{m} \\
& \text { (larger) }\end{aligned}$ & $24.1 \%$ & $75.9 \%$ & $90.5 \%$ & $9.5 \%$ \\
\hline
\end{tabular}

B. Cell size based on protein expression level

\begin{tabular}{lcc} 
& \multicolumn{2}{c}{ CD44 $^{\text {low } C D 25} 5^{+}$cell diameter } \\
\cline { 2 - 3 } Protein and expression level & $\begin{array}{c}<8.5 \mu \mathrm{m} \\
\text { (expected) }\end{array}$ & $\begin{array}{c}\geqslant 8.5 \mu \mathrm{m} \\
\text { (larger) }\end{array}$ \\
\hline Low levels of cyclin A & $95.7 \%$ & $4.3 \%$ \\
High levels of p27 & $97.9 \%$ & $2.1 \%$ \\
\hline
\end{tabular}

C. Cyclin A expression in $C D 44^{\text {low }} \mathrm{CD} 25^{+}$thymocytes from normal and mutant mice

\begin{tabular}{lcc} 
& \multicolumn{2}{c}{ Cyclin A expression } \\
\cline { 2 - 3 } Mouse strain & low & high \\
\cline { 2 - 3 } C57.BL/6 (normal) & $84.2 \%$ & $15.8 \%$ \\
TCR deficient $(\beta$ and $\delta)$ & $98.2 \%$ & $1.80 \%$ \\
\hline
\end{tabular}

the $\mathrm{L}$ subset. Likewise, the $62-\mathrm{kD}$ cyclin $\mathrm{B}$, detectable in low levels in $\mathrm{CD} 25^{+}$cells (Fig. 6B, CD $44^{\text {low }} / \mathrm{CD} 25^{+}$) could be largely attributed to the $\mathrm{L}$ subset (Fig. 6B, lane $\mathrm{L}$ ), with little present in the $\mathrm{E}$ subset (Fig. 6B, lane E). Cyclin B was readily detected in CD25- cells (Fig. 6B, $\mathrm{CD} 44^{\text {low }} / \mathrm{CD}^{2} 5^{-}$). The Western blot shown in Figure $6 \mathrm{~B}$ includes the human non-Hodgkin's lymphoma Manca (Hayday et al. 1984; Marraccino et al. 1992) as a positive control (Fig. 6B, Manca), along with an Sf9 cell lysate programmed with a baculovirus clone of cyclin $\mathrm{B}$ /a kind gift of David Morgan, University of California, San Francisco, CA) (Fig. 6B, SF9 cyclin B).

Retinoblastoma $\langle\mathrm{Rb}\rangle$ is another protein, the expression of which can indicate cell cycle status. Whereas $\mathrm{Rb}$ is expressed throughout the cell cycle, it is hypophosphorylated at the start of $G_{1}$ and hyperphosphorylated at mid-late $G_{1}$, yielding a protein of reduced mobility in SDS-PAGE gels (DeCaprio et al. 1992; Wang et al. 1995). As can be seen in Figure 6C (Thymic Rb), total thymocyte $\mathrm{Rb}$ is a mixture of the fast-running hypophosphorylated form of $\mathrm{Rb}$ and the slower running hyperphosphorylated form of $\mathrm{Rb}$. Two independent lysates of CD25 cells displayed mostly the fast-running, hypophosphorylated form [lanes $\left.\mathrm{CD} 44^{\text {low }} / \mathrm{CD} 25^{+}(1),(2)\right]$, whereas $\mathrm{CD} 25^{-}$cells displayed mostly the slow-running, hyperphosphorylated form $\left(\mathrm{CD} 44^{\mathrm{low}} / \mathrm{CD} 25^{-}\right)$. The CD $25^{+} \mathrm{E}$ subset displayed almost exclusively the hypophosphorylated form (lane E), whereas the $L$ subset phenocopied CD25- cells, in containing mostly hyperphosphorylated $\mathrm{Rb}$ (lane $\mathrm{L}$ ).

Finally, total $\mathrm{CD} 25^{+}$and $\mathrm{CD} 25^{-}$cell lysates were examined for the expression of cdc2 protein, by immunoprecipitation, followed by Western blot. In $\mathrm{CD} 25^{-}$extracts, all three forms of cdc2 were detectable as a triplet of bands at $\sim 30 \mathrm{kD}$ (Fig. $6 \mathrm{D}$, arrow). In contrast, in total $\mathrm{CD} 25^{+}$extracts, only very small amounts of cdc 2 were detectable and that which was detectable was predominantly the fastest migrating band of the triplet (Fig. 6D, lane 21, the inactive form of cdc2 (Solomon et al. 1990). Chromatography with pl3 Sepharose also failed to detect significant levels of cdc2 protein in $\mathrm{CD} 25^{+}$extracts (data not shown), ruling out the possibility that $\operatorname{cdc} 2$ was present but in a form cryptic to the antisera used. Furthermore, based on activity measurements (see below), the little cdc2 detectable in $\mathrm{CD} 25^{+}$cells was again mostly attributable to $\mathrm{L}$ cells.

\section{Cell cycle kinase activity assays}

$\mathrm{G}_{1}$ cells ordinarily display CDK6 activity and begin to display CDK2 activity as they progress toward and through S (Sherr and Roberts 1995). The activity of cdc2 is associated with the onset of $\mathrm{M}$. It has not been possible to assay directly CDK6 activity in $\mathrm{CD} 25^{+}$cells, because of the limiting recovery of primary cells /see yields, above). However, it was possible to assay CDK2 and cdc2 activities. Extracts of each subset were prepared as described (Koff et al. 1992), quantitated for cell equivalence, and imunoprecipitated with either normal rabbit serum (control) or either of two rabbit sera raised respectively against the carboxyl termini of cdc2 and CDK2. The capacity of each to phosphorylate histone $\mathrm{Hl}$ as a target substrate was then measured. Because of the limiting number of thymocytes available, peripheral blood $\mathrm{T}$ cells were used in preliminary studies to establish linear ranges for antibody and substrate concentration (e.g., Firpo et al. 1994), so that a quantitative estimate of $\mathrm{CDK} 2$ and cdc2 activities, respectively, could be made.

Both CD25 $5^{+}$cells and CD $25^{-}$cells displayed measurable CDK2 activity, compared with the phosphorylation of histone $\mathrm{Hl}$ in immunoprecipitates with normal rabbit sera $\{$ Fig. $7 \mathrm{~B}$ |. In contrast, $\mathrm{cdc} 2$ activity was only measurable ( - 100-fold above background) in CD25- cells (Fig.

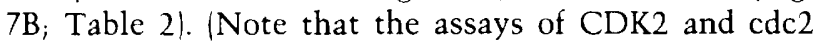
were independent and that Fig. $7 \mathrm{~B}$ is not meant to imply that CDK2 activity is greater than cdc2 activity in CD25- cells.) When E cells and $L$ cells were assayed in a second set of experiments (in parallel so that relative kinase activities in the two cell types could be reliably compared), CDK2 activity was detected in both cell types (Fig. 7A), with higher levels in the $\mathrm{L}$ subset. These data are consistent with the capacity to detect CDK2 in bulk CD25- cells. In contrast, whereas cdc2 activity was detected at $\sim 13$-fold above background in the $\mathrm{L}$ subset lysates, it was undetectable above background in CD25 ${ }^{+}$ $\mathrm{E}$ cells (Fig. 7A). This is consistent with the failure to 
A

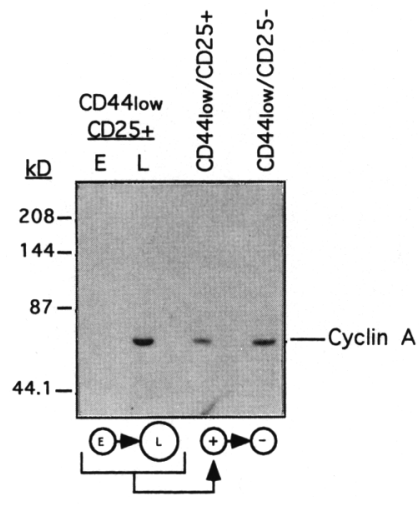

C

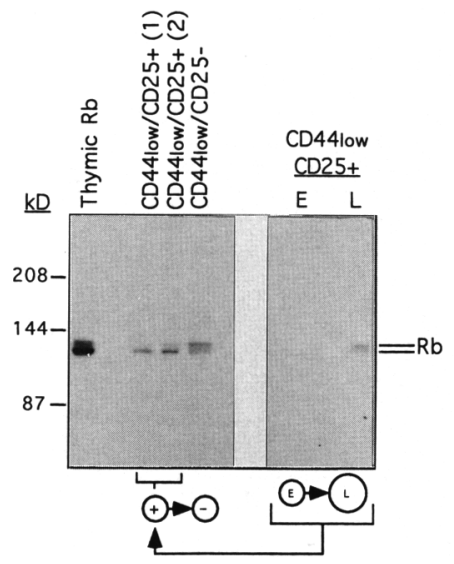

B

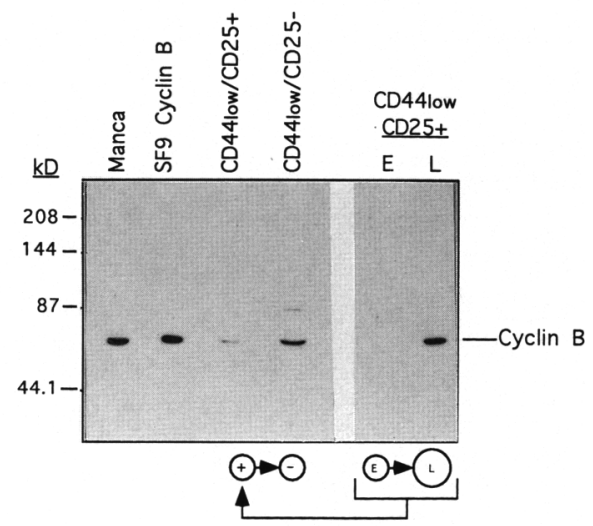

D

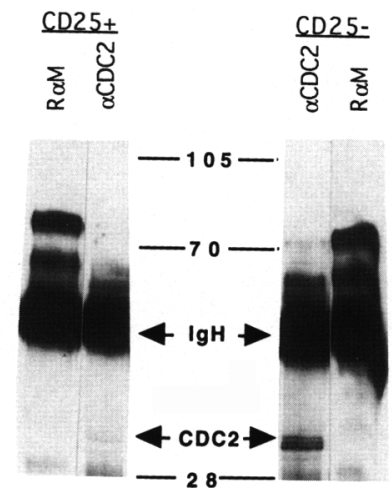

Figure 6. Immunoblots of cyclin $\mathbf{A}$, cyclin $\mathrm{B}, \mathrm{Rb}$, and a cdc2 immunoprecipitation. Lysates of total $\mathrm{CD} 25^{+}$cells, CD25 ${ }^{+}$ E cells, CD $25^{+} \mathrm{L}$ cells, and CD25- cells were analyzed by SDS-PAGE and Western immunoblotting as indicated for cyclin $\mathrm{A}$ $(A)$, cyclin $\mathrm{B}(B)$, and $\mathrm{Rb}$ protein $(C)$. The cyclin $\mathrm{B}$ immunoblot includes the human non-Hodgkin's lymphoma Manca as a positive control $(B$, lane 1$)$, along with an Sf9 cell lysate programmed with a baculovirus clone of cyclin $\mathrm{B}$, running as a $5-\mathrm{kD}$ larger protein $(B$, lane 2$)$. The $\mathrm{Rb}$ immunoblot includes whole thymus lysate as a positive control for both phosphorylation forms of $\mathrm{Rb}(C$, lane 1$) .(D) \mathrm{cdc} 2$ expression was analyzed by immunoprecipitation from total $\mathrm{CD} 25^{+}$cells and $\mathrm{CD} 25^{-}$cells and similar analysis of the precipitated material. $(D$, lanes 1,4 ) Normal rabbit serum was used as the control for the immunoprecipitation. detect significant cdc2 activity in bulk $\mathrm{CD} 25^{+}$cells /Fig. $7 \mathrm{~B}$ ), because the $\mathrm{L}$ subset comprises only $\sim 10 \%$ of the total $\mathrm{CD} 25^{+}$subset. Thus, subdivision of $\mathrm{CD} 25^{+}$cells into $\mathrm{E}$ and $\mathrm{L}$ subsets operationally defines a transition from low to higher CDK2 activity and negligible to high $\mathrm{cdc} 2$ activity in parallel with increases in cyclins $\mathrm{A}$ and $B$ (Figs. 5 and 6), decreases in p27 (Fig. 5), induction of DNA synthesis (Fig. 2), and $\beta$ selection (Fig. 3).

\section{RAG1 and RAG2 expression}

Recent work in vitro has shown that cdc2 kinase can phosphorylate RAG2 protein and through this phosphorylation can target RAG2 for rapid degradation (Lin and Desiderio 1993, 1995). Because of the significant change in cdc2 activity across the $\mathrm{E}$ to $\mathrm{L}$ transition, the relative levels of RAG2 protein in the two subsets /as well as in
A

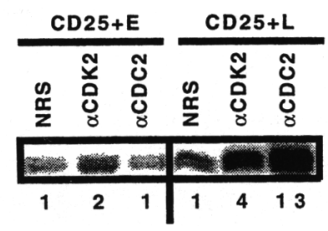

B

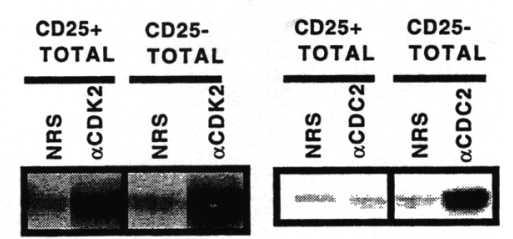

Figure 7. Immunoprecipitable $\mathrm{Hl}$ kinase activity analysis. (A) CDK2 and cdc2 activity from $\mathrm{CD} 25^{+} \mathrm{E}$ and $\mathrm{L}$ cells; $(B) \mathrm{CDK} 2$ and cdc2 activity from $\mathrm{CD} 25^{+}$and $\mathrm{CD} 25^{-}$cells. The lysates were immunoprecipitated with the antibody indicated above each lane. Shown is a PhosphorImager representation of the relative kinase activity using histone $\mathrm{Hl}$ as a substrate. Under each lane in $A$ is the fold increase in $\mathrm{Hl}$ kinase activity compared with the amount of activity precipitated with the normal rabbit serum for each type of cell. This was not possible in $B$, because assays were performed at separate times. 
$\mathrm{CD} 25^{+}$and $\mathrm{CD} 25^{-}$cells as a wholel were examined by Western blot using affinity-purified, polyclonal rabbit anti-RAG antibodies, raised against fusions of the Pseudomonas exotoxin with portions of RAG2. The specificity of the antisera has been extensively determined, for example, by the capacity to detect the Pseu. damonas exotoxin fusions, but not Pseudomonas exotoxin (T.M.J. Leu, K.R. McConnel, E. Corbett, S. Bennet, and D.G. Schatz, in prep.). In Figure 8A, RAG2 is detected as a protein of $\sim 58 \mathrm{kD}$ in $\mathrm{CD} 25^{+}$cells $\left(\mathrm{CD} 44^{\text {low }} /\right.$ $\mathrm{CD} 25^{+}$), that compares well with the detection of a 63 kD RAG2 protein, expressed in a B-cell lymphoma transfected with a RAG2 gene tagged with a sequence encoding an additional $5 \mathrm{kD}$ of protein (Fig. 8A, Ind $\operatorname{Tr} \mathrm{B}$ Ly). RAG2 protein was equally well detected in the purified E subset (Fig. 8A, lane E). In contrast, much lower levels of RAG2 were detectable in $\mathrm{CD} 25^{+} \mathrm{L}$ cells (Fig. $8 \mathrm{~A}$, lane $\mathrm{L}$ ), in which the prevalent (albeit weak) band migrated $\sim 4 \mathrm{kD}$ more slowly. Likewise, virtually no RAG2 was detected in CD25- cells (Fig. 8A, CD $44^{\text {low }}$ / $\mathrm{CD} 25^{-}$) [the weak signal from a protein running slighlty faster than RAG2 is a non-RAG2-related protein present in many cell types and detected as a cross-reactive specificity of the polyclonal anti-RAG2 serum (data not shown)]. To assess more accurately the relative levels of RAG2 in $\mathrm{CD} 25^{+}$and $\mathrm{CD} 25^{-}$cells, a series of Western blots were performed across a titration of lysate concentrations of the two subsets, for example, $0.125 \times \mathrm{CD} 25^{-}$ versus $2.5 \times \mathrm{CD} 25^{-}, 0.25 \times \mathrm{CD} 25^{+}$versus $5 \times \mathrm{CD} 25^{-}$, etc. The data were then subjected to densitometry, which confirmed linear range. Reproducibly, the difference in RAG2 concentration in the two subsets was $\sim 22.5$-fold (data not shown). Coincidentally, phosphorylation of RAG2 by cdc2-type activities is estimated to destabilize it by $\sim 20$-fold (Lin and Desiderio 1995).

The reduction in RAG2 levels in $\mathrm{CD} 25^{+} \mathrm{L}$ cells and in $\mathrm{CD} 25^{-}$cells is transient. By the time thymocytes have progressed to the DP stage (Fig. 4), RAG2 protein is reexpressed (Fig. 8B). The reduction in RAG2 levels in $\mathrm{CD} 25^{+} \mathrm{L}$ cells and in $\mathrm{CD} 25^{-}$cells is also selective. Analysis of RAGl using antisera raised in parallel with those raised against RAG2 revealed a predicted protein of $\sim 125 \mathrm{kD}$, which was present approximately cqually in total CD $25^{+}$cells, CD $25^{+}$E cells, CD $25^{+} \mathrm{L}$ cells, and $\mathrm{CD} 25^{-}$cells (Fig. 8C). (The other bands on the gel are variably detected, again through cross-reactivity of the polyclonal sera, but they also show no distinction in representation between either $\mathrm{E}$ and $\mathrm{L}$ cells or $\mathrm{CD} 25^{+}$and CD25- cells).

To determine that the selective changes seen in RAG2 expression were generally representative of cells in the $\mathrm{CD} 25^{+}$and $\mathrm{CD} 25^{-}$subsets, RAG2 protein expression was assessed by immunofluorescent confocal microscopy. RAG2 was clearly detected as a nuclear protein in most CD $25^{+}$cells (Fig. 9a). By serial optical sectioning, it could be determined that the larger cells /candidate L subset cells) showed weaker staining. The residual staining may represent a combination of residual 58kD RAG2, as detected by Western blot (Fig. 8A) and, possibly, modified forms of RAG2, such as the $62-\mathrm{kD}$
A

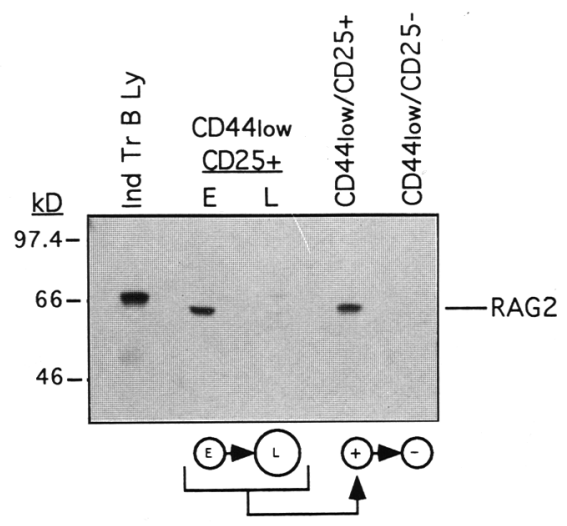

B

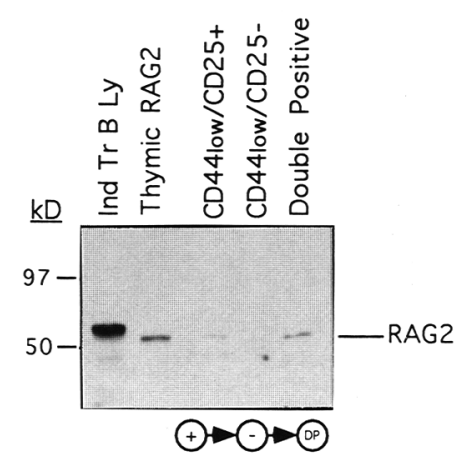

C

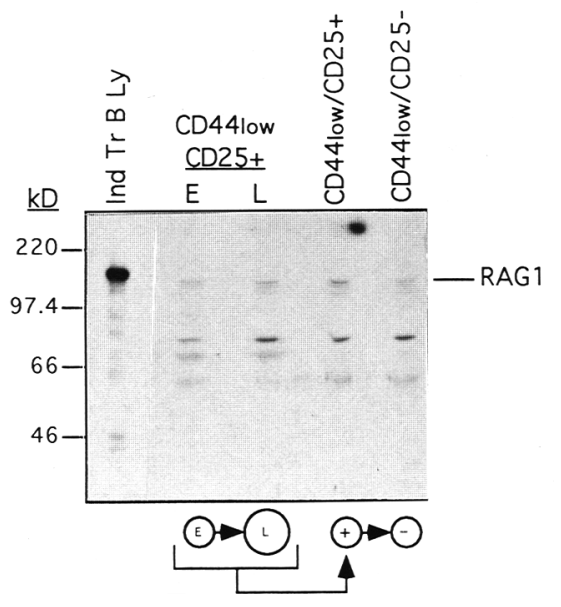

Figure 8. Immunoblots of RAG1 and RAG2. Lysates of total CD25 cells, CD $25^{\circ}$ E cells, CD25 $5^{\circ}$ cells, and CD25 cells were analyzed by SDS-PAGE and Western immunoblotting as indicated for RAG2 $|A|$ and RAG $1\{C \mid$. |The first lane in each gel is a lysate of a $B$ lymphoma transfected and induced to produce RAGl and RAG2, tagged by a sequence making the protein run $5 \mathrm{kD}$ larger. $\mid(B)$ Lysates of total thymus, total CD $25^{-}$cells, CD25 cells, and DP thymocytes were similarly analyzed for RAG2.

form weakly detected in CD2 $5^{+} \mathrm{L}$ cell lysates (Fig. 8A). Moreover, the confocal representation of RAG2 is not strictly quantitative. This notwithstanding, $\mathrm{CD} 25^{-}$ cells showed very weak staining |arrows in Fig. 9b), consistent with the almost total absence of RAG2 protein by Western blot (Fig. 8A). As controls, CD25 ${ }^{+}$cells from 

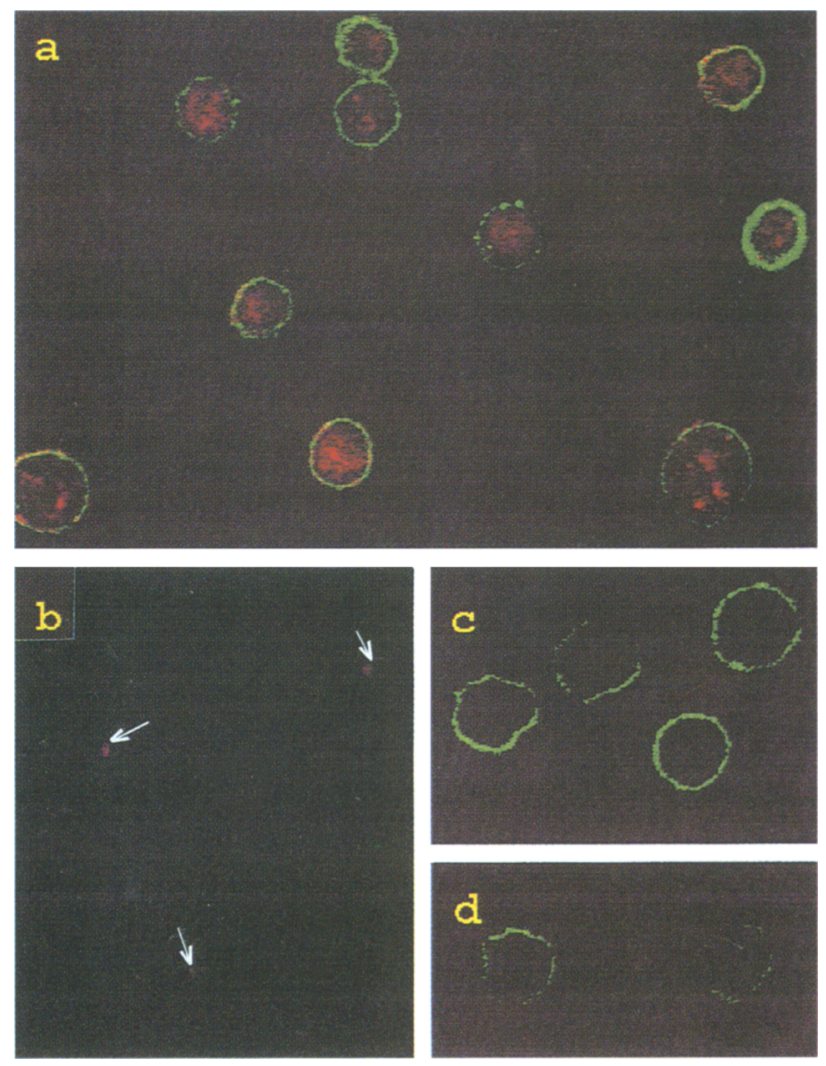

Figure 9. Confocal immunofluorescence analysis of RAG2. $|A|$ $\mathrm{CD} 25^{-}$thymocytes from normal mice were stained with an antibody specific for RAG2 followed by a secondary antibody conjugated to Lissamine rhodamine, which is visualized as red staining. CD25 cells retain the FITC-conjugated anti-CD25 antibody staining used in the sorting, which appears as a green ring around the perimeters of the cells. CD25 thymocytes from normal mice $(B)$ and $C D 25^{\circ}$ thymocytes from RAG-deficient mice $(C)$ were stained similarly with an antibody specific for RAG2. (D) CD25 thymocytes from normal mice were stained with the secondary antibody alone.

RAG - / - mice and CD25+ cells stained with the conjugated secondary antibody alone showed only the FITC staining for CD25 (Fig. 9c,d). In further studies, almost all $\mathrm{HSA}^{\text {hi }} \mathrm{CD} 44^{\text {low }} \mathrm{CD} 25^{+}$thymocytes from $\mathrm{TCR} \beta \times \delta$ deficient mice stained clearly positive for RAG2 protein (data not shown).

\section{Discussion}

An important goal of immunological research is to determine the role in development of pre-antigen receptors, namely the pre-B-cell receptor, and the pre-TCR. These receptors interact presumably with autologous ligands on the stroma and may provide insight into the evolution of receptors that recognize foreign antigens from receptors that originally recognized self ligands. As part of this goal, a definition is required of the events surrounding pre-antigen receptor selection. In this paper the definition of events proximal to pre-TCR signaling in vivo is significantly improved by an improved delineation of where in T-cell development $\beta$ selection is likely to occur. This has been accomplished by the novel definition of a subset of $\mathrm{CD}^{-} \mathrm{CD}^{-} \mathrm{HSA}^{+} \mathrm{CD} 44^{\text {low }}$ $\mathrm{CD} 25^{+}$thymocytes that is highly enriched in productively rearranged TCR $\beta$ chain genes. The importance of productive TCR gene rearrangement in the genesis of this cell subset is indicated by its acute depletion in mice congenitally unable to synthesize the pre-TCR (Fig. 2C). This subset has been defined as the $\mathrm{L}$ subset because although it is as yet indistinguishable by surface markers from the bulk of $\mathrm{HSA}{ }^{+} \mathrm{CD} 44^{\text {low }} \mathrm{CD} 25^{+}$cells, the cells are mostly larger than other $\mathrm{HSA}^{+} \mathrm{CD} 44^{\text {low }} \mathrm{CD} 25^{+}$ cells (the E subset).

The determination that the $\mathrm{L}$ subset clearly differs from the E subset in cell cycle status, as summarized in Table 3, confirms our previous hypothesis that cell cycle activation is a very early event in response to productive TCR $\beta$ chain gene rearrangement (Dudley et al. 1994). Although it has not been formally proven that E cells are precursors to $\mathrm{L}$ cells, this is the interpretation that best fits the data, for example, that there is very little TCR $\beta$ chain gene rearrangement prior to the $\mathrm{HSA}^{+} \mathrm{CD} 44^{\text {low }}$ $\mathrm{CD}^{+} 5^{+}$cell stage (Godfrey et al. 1994) and that thymocytes from mutant mice defective in pre-TCR expression (owing to a variety of defects) all show normal thymocyte development up to and including the bulk of the $\mathrm{HSA}^{+} \mathrm{CD} 44^{\text {low }} \mathrm{CD} 25^{+}$cell stage, that is, the E subset (e.g., Fig. 2C).

Because the expansion in thymocyte numbers that occurs between the late DN stage and the DP stage appears to be the greatest expansion in thymocyte numbers that occurs, one might conclude that the pre-TCR is the most important growth factor receptor for thymocytes and is thus a primary determinant of the number of $T$ cells an animal makes. This emphasizes the codependent interplay of the regulation of cell proliferation and cell differentiation during T-cell development-the pre-TCR, a highly $T$ cell-specific differentiation product, promotes a cell cycle transition that is in turn tightly associated with the transient down-regulation of further RAG2-mediated differentiation.

The findings presented in this paper lay the ground for a more precise analysis of how the pre-TCR functions, in particular, whether it functions by the same mechanism as do other growth-stimulatory receptors, such as that for epidermal growth factor. Although the precise interrelationship of growth-stimulatory factors with the cell cycle has not been clarified, it is generally believed that a crucial consequence of their action may be cyclin-D activation and, as a result, phosporylation of $\mathrm{Rb}$. Such a mechanism is plausible for the pre-TCR, based on our findings that $\mathrm{Rb}$ in $\mathrm{E}$ cells is almost entirely hypophosphorylated, indicating in turn that cyclin D-dependent kinases in E cells are inactive. Moreover, an analogous situation may hold in B-cell development where Rosenberg and colleagues showed that in tissue culture, immunoglobulin light-chain gene rearrangement is restricted to a period of the cell cycle in which $\mathrm{Rb}$ is hypophosphorylated (Wang et al. 1995). In studies of 
Table 3. Data summary

\begin{tabular}{|c|c|c|c|c|}
\hline & \multicolumn{3}{|c|}{ Thymocyte population } & \multirow[b]{3}{*}{ Analysis } \\
\hline & \multicolumn{2}{|c|}{$\mathrm{CD} 44^{\text {low }} \mathrm{CD} 25^{+}$} & \multirow[b]{2}{*}{$\mathrm{CD} 44^{\text {low }} \mathrm{CD} 25^{-}$cells } & \\
\hline & E cells & $\mathrm{L}$ cells & & \\
\hline DNA content: $2 \mathrm{~N}$ & $98 \%$ & $34 \%$ & $76 \%$ & FACS analysis \\
\hline$>2 \mathrm{~N}$ & $2 \%$ & $66 \%$ & $24 \%$ & \\
\hline TCR $\beta$ joins & random & in-frame & in-frame & PCR-RFLP \\
\hline Cyclin D2 & + & + & + & confocal immunofluorescence \\
\hline Cyclin D3 & ++ & ++ & ++ & \\
\hline Cyclin E & +++ & +++ & +++ & \\
\hline $\mathrm{p} 27$ & +++ & $+1-$ & + & \\
\hline Cyclin A & - & +++ & N.D. & \\
\hline CDK2 & + & + & + & \\
\hline Cyclin B & $+1-{ }^{a}$ & + & ++ & \\
\hline RAG2 & ++ & + & $+1-$ & \\
\hline Cyclin A & - & +++ & ++ & immunoblot \\
\hline Cyclin B & $+1-$ & $++t$ & ++ & \\
\hline $\mathrm{Rb}$ phosphorylation & hypo & hyper & hyper & \\
\hline $\operatorname{cdc} 2$ IP & & & $+++c$ & \\
\hline RAGl & ++ & ++ & ++ & \\
\hline RAG2 & +++ & $+1-$ & $+1-$ & \\
\hline CDK2 & $2 \mathrm{x}$ & $4 \mathrm{x}$ & $100 x$ & immunoprecipitable kinase activity ${ }^{d}$ \\
\hline $\operatorname{cdc} 2$ & $1 \mathrm{x}$ & $13 x$ & $102 x$ & \\
\hline
\end{tabular}

(N.D.) Not done.

${ }^{\mathrm{a}}$ Edge or cytoplasmic staining.

bPredominantly inactive form only.

'Includes active form.

${ }^{\mathrm{d}}$ Expressed as activity above background.

human peripheral blood $\mathrm{T}$ cells, it was suggested that the TCR activated progression through $G_{1}$ via cyclin D-dependent kinases, and necessary costimulation through the IL-2 receptor relieved the inhibitory action of CDI p27 (Firpo et al. 1994). A priori, a directly analogous mechanism might be postulated here, given that cells on which $\beta$ selection occurs express CD25, the IL-2R $\alpha$ chain. However, there are currently no data suggesting the significance of $\mathrm{CD} 25$ as a growth factor receptor in thymocyte development. A positive feature of using $\mathrm{CD} 25^{+} \mathrm{E}$ thymocytes to further study growth factor signaling in primary cells is the homogeneity of the cells' differentiation phenotype. In contrast, peripheral blood $T$ cells contain cells of multiple phenotypes, among which there are further subsets of naive and memory cells.

How is cyclin D-dependent kinase activity inhibited in E cells during gene rearrangement? All cells stained positively for cyclin $\mathrm{D}$. Moreover, our reproducible capacity to measure CDK2 activity in $\mathrm{HSA}^{+} \mathrm{CD} 44^{\text {low }}$ $\mathrm{CD} 25^{+} \mathrm{E}$ cells (Fig. 7) suggests that the cells have reached mid- $G_{1}$ (i.e., they are not in $G_{0}$ ). Rather, it might be that $\mathrm{E}$ cells, similar to those exposed to the antimitogenic cytokine TGF $\beta$, contain a member of the INK family of inhibitors (Reynisdottir et al. 1995), along with p27, and that both $\mathrm{p} 27$ and INK cooperate to maintain cells in an $\mathrm{Rb}$ hypophosphorylated state.

This notwithstanding, there are other events besides cyclin- $\mathrm{D}$ activation that may be very early consequences of productive TCR $\beta$ chain gene rearrangement; for example, an increase in CDK2-dependent kinase activity (Fig. 7), perhaps owing to the increase in the amount of cyclin $\mathrm{A}$ and the decrease in the amount of p27 (Fig. 5); increases in cyclin B (Fig. 6); and the striking induction of cdc2 activity (Fig. 7). A summary of the pre-TCR-dependent progression of thymocytes from $\mathrm{CD} 25^{+} \mathrm{E}$ cells through $\mathrm{CD} 25^{+} \mathrm{L}$ cells to $\mathrm{CD} 25^{-}$cells is illustrated in Table 3. It is evident that to understand the mechanism that coordinates clonal expansion with gene rearrangement we must determine the temporal relationship of the three events: cyclin D-dependent kinase activation, increases in CDK2 activation, and increases in cdc2 protein expression and activity. Studies exploiting novel genetically altered mice are currently in progress to determine such a temporal relationship.

Movement of cells from the HSA ${ }^{+} \mathrm{CD} 44^{\text {low }} \mathrm{CD} 25^{+} \mathrm{L}$ subset into the $\mathrm{HSA}^{+} \mathrm{CD} 44^{\text {low }} \mathrm{CD} 25^{-}$pool and thence to DP cells is associated with several repeated rounds of cell division, which are also a consequence, direct or otherwise, of productive TCR $\beta$ gene rearrangement. The 
development of $\gamma \delta \mathrm{T}$ cells does not depend on expression of the TCR $\beta|+|$-pre-TCR, and most $\gamma \delta$ T cells lack complete $V(D) / \beta$ gene rearrangements (Dudley et al. 1994). Thus, most $\gamma \delta \mathrm{T}$ cells would not experience the proliferation associated with the $\mathrm{CD} 25^{+}$to $\mathrm{CD} 25^{-}$to $\mathrm{DP}$ transition. This may in part explain why circulating $\gamma \delta$ T-cell numbers are commonly 10-50 times lower than $\alpha \beta$ T-cell numbers (Hayday 1992). At the same time, among $\gamma \delta \mathrm{T}$ cells that contain rearranged $V(D) / \beta$, productive rearrangements are disproportionately common $(>33 \%)$, consistent with those cells benefiting from preTCR-stimulated expansion before the completion of their differentiation as $\gamma \delta \mathrm{T}$ cells (Dudley et al. 1994).

Because it was shown recently that many $\gamma \delta \mathrm{T}$ cells and $\alpha \beta$ T cells develop along a common lineage (Dudley et al. 1995; Livac et al. 1995), it is intriguing to consider that productive rearrangement of TCR $\gamma$ and TCR $\delta$ genes induces exit from $G_{1}$, in which gene rearrangement was occurring, but does not induce the repeated proliferation associated with $\beta$ selection. This is perhaps attributable to intrinsic differences in the signaling mechanism employed by the $\gamma \delta$ TCR. Consistent with this, we and our colleagues have recently discovered that in response to antigen stimulation in the spleens of mice, $\gamma \delta \mathrm{T}$ cells generally expand less than do $\alpha \beta$ T cells $(W$. Pao, L. Wen, A. Smith, A. Judge, I. MacLennan, M.J. Owen, and A.C. Hayday, in prep.). Thus, further comparison of pre-TCR signaling and $\gamma \delta$ TCR signaling in thymocytes may provide important information concerning the signaling pathway that regulates the extent of cell proliferation following growth factor receptor engagement. This pathway may critically involve costimulation through other cell surface receptors that function in concert with the antigen and pre-antigen receptors.

Judging from the phenotype of the pT $\alpha-/-$ mouse, in which few $\alpha \beta$ T cells develop (Fehling et al. 1995), thymocyte expansion is not the only consequence of preTCR action. Rather, essential differentiation events would also seem contingent on pre-TCR signaling. These may include activation of the TCR $\alpha$ locus for subsequent expression and rearrangement. Consistent with an effect of productive TCR $\beta$ chain rearrangment (and presumably pre-TCR signaling/ on thymocyte differentiation is the transient and selective down-regulation of RAG2 protein levels that accompanies the transition to CD25- cells. Changes in RAG2 protein levels during avian thymocyte development were also reported previously (Ferguson et al. 1994), although in that case the study of RAG2 protein in DN cells could not be completed and, thus, no close correlation with $\beta$ selection was established.

The RAG2 regulation reported here is strikingly consistent with the 20-fold decrease in RAG2 stability in vitro reported after its phosphorylation by CDC2 (Lin and Desiderio 1993, 1995). In turn, this finding significantly strengthens the hypothesis that $\mathrm{CDK} 2 / \mathrm{cdc} 2$ is a bona fide regulator of RAG2 in vivo. Because the CDK2/ cdc 2 activites are promoted in vivo by productive TCR $\beta$ chain gene rearrangement, this would link the successful rearrangement of a TCR $\beta$ chain with the likely transient down-regulation of further TCR gene rearrangement. Thus, a contribution to allelic exclusion at the TCR $\beta$ locus may be an important by-product of pre-TCR signaling.

This is not to suggest that pre-TCR-associated cell cycle transitions are essential for allelic exclusion at the TCR $\beta$ chain locus. Rather, allelic exclusion will be brought about when the TCR $\beta$ locus is rendered "permanently" inaccessible to further gene rearrangement. Such an event may be analogous to structural alterations of chromosome structure that occur at the yeast matingtype locus, also in response to a signaling cascade promoted by engagement of a cell surface receptor (Pringle and Hartwell 1981).

Instead, the pre-TCR-associated cell cycle transition may, through effects on RAG2, create a window of time in which gene rearrangement is reduced while the TCR $\beta$ locus is rendered inaccessible. In support of this idea, allelic exclusion is more efficient after successful rearrangement at the TCR $\beta$ locus, an event associated with a cell cycle progression, than it is after successful rearrangement at the TCR $\alpha$ locus, an event that is not associated with cell cycle progression (Padovan et al. 1993). The signal for the recombination machinery to be downregulated after productive $\mathrm{TCR} \alpha$ gene rearrangement seems not to be the completion of gene rearrangement per se, but the successful engagement of a complete TCR by major histocompatibility complex (MHC) products (Turka et al. 1991). Likewise, cell cycle progression and efficient allelic exclusion both appear to be associated with IgH locus rearrangement and the action of the preB-cell receptor, whereas productive IgL chain gene rearrangement is associated with neither efficient allelic exclusion nor cell cycle progression /Schlissel and Morrow 19941.

There are numerous precedents for two-step changes in gene expression in response to a change in a cell's status. For example, on differentiation of the human myelogenous cell line, HL60, c-myc expression is first down-regulated post-transcriptionally, followed some hours later by down-regulation at the promoter (Siebenlist et al. 1988). Such two-step mechanisms are interpreted as manifesting the progression from a rapid response to a permanent change. The proliferative consequences of productive TCR $\beta$ chain rearrangement and any significant effects on allelic exclusion may themselves be segregated by mutation. For example, in CD $3 \zeta-/-$ mice, TCR $\beta$ chain allelic exclusion occurs (Liu et al. 1993), whereas the significant expansion in thymocyte numbers that ordinarily accompanies the DN to DP transition does not (Crompton et al. 1994).

Future studies are needed to elucidate several issues concerning RAG2 regulation in vivo. For example, is it most closely correlated with increases in CDK2 activity, perhaps driven by the increases in cyclin $\mathrm{A}$ that are apparent as cells transit to the CD25 ${ }^{+}$L subset stage? Or is it most closely correlated with the significant increases in cdc2 activity that similarly accompany the $\mathrm{CD} 25^{+}$to $\mathrm{CD} 25^{-}$transition? A contribution of RAG2 RNA regulation, suggested previously by MacDonald and col- 
leagues (Wilson et al. 1994), also needs to be quantitated accurately now that the $E$ and $L$ subsets have been defined. Such studies promise to improve our understanding of how transcriptional and post-transcriptional events in T-cell differentiation both coordinate and are coordinated by cell cycle regulation in vivo.

\section{Materials and methods}

Animals and cell sorting

C57.BL/6 mice were obtained from Jackson Labs and the Charles River Company. Normally, female mice at or near 3-4 weeks of age were used. Thymi were teased and ground into single-cell suspensions. Thymocytes were guinea pig complement (GIBCO) depleted of $\mathrm{CD}^{+}{ }^{+}$and $\mathrm{CD} 8^{+}$cells (CD4- and CD8-specific hybridoma supernatant was kindly provided by I.N. Crispe, Yale University, New Haven, CT), stained, and sorted on a FACStar Plus flow cytometer, as described previously (Wilson et al. 1988; Dudley et al. 1994). Antibodies and other staining reagents used for FACS sorting included $\alpha \mathrm{CD} 25$ FITC (Pharmingen), $\alpha$ HSA-PE (Pharmingen), $\alpha$ CD4-Red 670 (Sigma), $\alpha$ CD44-biotin (Pharmingen), and Avidin D-Texas Red (Vector).

\section{DNA content analysis}

Standard staining of cell populations by propidium iodide was done as described previously (Crissman et al. 1976) and analyzed using doublet discrimination on the FACS.

\section{PCR-RFLP analysis}

For each experiment, $1 \times 10^{6}$ cells of each subset were used. Details of the technique and PCR primers used have been described previously (Mallick et al. 1993; Dudley et al. 1994).

\section{Immunofluorescent microscopy}

Cyclin A, cyclin E, CDK2, and p27 rabbit antisera (Koff et al. 1992), cyclin D2, cyclin D3 rabbit antisera (Santa Cruz), and purified mouse monoclonal specific for cyclin B1 (Pharmingen) have been described and were used to stain cells preincubated with FITC-conjugated anti-CD25 (Pharmingen). Affinity-purified anti-RAG1 and anti-RAG2 rabbit antisera raised against amino acids 56-123 of RAG1 and amino acids $70-516$ of RAG2 respectively fused with the Pseudomonas exotoxin protein (T.M.J. Leu, K.R. McConnel, E. Corbett, S. Bennet, and D.G. Schatz, in prep.) were also used to stain similar cells. Reactivity was detected with a Lissamine rhodamine-conjugated goat antirabbit immunoglobulin or goat anti-mouse immunoglobulin (Jackson Immuno Labs). A Zeiss Axiovert 10 microscope with a Bio-Rad MRC-600 laser-scanning confocal imaging system and MRC-600 confocal microscope operating software version 6.05.4 was utilized for all studies.

\section{Immunoprecipitation, gel electrophoresis, and immunoblotting}

cdc2 immunoprecipitation has been described (Koff et al. 1992). In all other cases, whole-cell lysate was used. Cells were enumerated and then lysed in an NP-40 lysis buffer containing five protease inhibitors and four phosphatase inhibitors. The protein concentration was determined by BCA assay and equivalent loading in Coommassie blue-stained gels. Defined quantities (normally $2.5 \times 10^{5}$ cells/lane) were electrophoresed in $6.5 \%$
(5\% for the Rb immunoblot) SDS-polyacrylamide gel electrophoresis (SDS-PAGE), transferred to PVDF membranes (Bio$\mathrm{Rad}$ ) using standard conditions. Cyclin-A rabbit antisenum was used as described (Koff et al. 1992) at a 1:500 dilution; monoclonal cyclin-B antibody (Santa Cruz) was used at a 1:1000 dilution; and monoclonal $\mathrm{Rb}$ antibody (Pharmingen) was used at a 1:1000 dilution. For RAG1 and RAG2 immunoblots, the membranes were incubated with 1:200 dilutions of either of the two affinity-purified rabbit sera raised against RAG1 and RAG2, respectively (see above). In all cases, reactivity was determined by HRP-conjugated secondary antibodies (Sigma) and enhanced chemiluminescence (ECL) (DuPont).

\section{Kinase assays}

For each experiment, $1 \times 10^{6}$ cells were immunoprecipitated with either normal rabbit serum, a carboxy-terminal peptidespecific CDK2 rabbit antiserum, or a carboxy-terminal peptidespecific CDC2 rabbit antiserum as described before (Koff et al. 1992). Relative histone $\mathrm{Hl}$ phosphorylation was measured and quantified using phosphorimaging.

\section{Acknowledgments}

This work has been supported by National Institutes of Health grants GM37759 (A.H.), GM52597 (A.K.), and AI32524 (D.G.S.), by a National Science Foundation predoctoral fellowship (E.S.H.), by an Immunology Training Grant (AI07019), by the Imperial Cancer Research Foundation (M.J.O.; T.C.), by the Swiss Bank Corporation (T.M.J.L.), by the Howard Hughes Medical Institute (D.G.S.), and by The Society of the Memorial Sloan-Kettering Cancer Center (A.K.). We thank Tom Taylor for cell sorting, Rocco Carbone for DNA analysis, Laurent Caron for confocal microscopy assistance and Sylvia Kim for technical expertise. We also thank William Pao, E.C. Dudley, and those referred to in the text and legends for the kind provision of antibodies and other reagents.

The publication costs of this article were defrayed in part by payment of page charges. This article must therefore be hereby marked "advertisement" in accordance with 18 USC section 1734 solely to indicate this fact.

\section{Note added in proof}

Since acceptance of this paper, Xu et al. [Proc. Nat]. Acad. Sci 93: $2167-2173(1996)]$ have refuted the link of thymocyte proliferation and allelic exclusion, based on the segregation of the two events in pT $\alpha-1-$ mice. As is discussed in this paper, this segregation was already evident in $\mathrm{CD} 3 \zeta-/-$ mice (Liu et al. 1993; Crompton et al. 1994|. Our contention is that cdc2/ CDK2-mediated selective down-regulation of RAG2 protein is likely an important component of a multicomponent process of efficient allelic exclusion, which occurs within the CD $25^{+}$subset, prior to and potentially independent of subsequent expansion at the CD25- stage. This issue is considered in the Discussion.

\section{References}

Crissman, H.A., M.S. Oka, and J.A. Steincamp. 1976. Rapid staining method for the analysis of deoxyribonucleic acid and protein in mammalian cells. I. Histochem. Cytochem. 24: 64 .

Crompton, T., M. Moore, H.R. MacDonald, and B. Malissen. 1994. Double-negative thymocyte subsets in CD3ל chain- 
deficient mice: Absence of $\mathrm{HSA}^{+} \mathrm{CD} 44^{-} \mathrm{CD} 25^{-}$cells. Eur. I. Immunol. 24: 1903-1907.

Davodeau, F., M.-A. Peyrat, I. Houde, M.-M. Mallet, G. De Libero, H. Vie, and M. Bonneville. 1993. Surface expression of two distinct functional antigen receptors on human gamma-delta T cells. Science 260: 1800-1802.

DeCaprio, J.A., J.W. Ludlow, D. Lynch, Y. Furukawa, J. Griffin, H. Piwnica-Worms, C.-M. Huang, and D.M. Livingston. 1992. The retinoblastoma-susceptibility gene product becomes phosphorylated in multiple stages during cell cycle entry and progression. Proc. Natl. Acad. Sci. 89: 1795-1798.

Dudley, E.C., H.T. Petrie, L.M. Shah, M.J. Owen, and A.C. Hayday. 1994. T cell receptor $\beta$ chain gene rearrangement and selection during thymocyte development in adult mice. $\mathrm{Im}$ munity 1: 83-93.

Dudley, E.C., M. Girardi, M.J. Owen, and A.C. Hayday. 1995. $\alpha \beta$ $\mathrm{T}$ cells and $\gamma \delta \mathrm{T}$ cells can share a late common precursor. Curr. Biol. 5: 659-669.

Fehling, H.J., A. Krotkova, C. Saint-Ruf, and H. von Boehmer. 1995. Crucial role of the pre-T-cell receptor $\alpha$ gene in development of $\alpha \beta$ but not $\gamma \delta$ T cells. Nature 375: 795-798.

Ferguson, S.E., M.A. Accavitti, D.D. Wang, C.L. Chen, and C.B. Thompson. 1994. Regulation of RAG-2 protein expression in avian thymocytes. Mol. Cell. Biol. 14: 7298-7305.

Firpo, J., A. Koff, M. Solomon, and J. Roberts. 1994. Inactivation of a CDK2 inhibitor during IL2 induced proliferation of human T lymphocytes. Mol. Cell Biol. 14: 4889-4901

Godfrey, D., J. Kennedy, P. Mombaerts, S. Tonegawa, and A. Zlotnik. 1994. Onset of TCR- $\beta$ gene rearrangement and role of TCR- $\beta$ expression during $\mathrm{CD} 3^{-} \mathrm{CD} 44^{-} \mathrm{CD} 8{ }^{-}$thymocyte differentation. I. Immunol. 152: 4783-4792.

Groettrup, M., K. Ungewiss, O. Azogui, R. Palacios, M.J. Owen, A.C. Hayday, and H. von Boehmer. 1993. A novel disulfidelinked heterodimer on pre- $\mathrm{T}$ cells consists of the $\mathrm{T}$ cell receptor $\beta$ chain and a 33kD glycoprotein. Cell 75: 283-294.

Hatakeyama, M., J.A. Brill, G.R. Fink, and R.A. Weinberg. 1994. Collaboration of $G_{1}$ cyclins in the functional inactivation of the retinoblastoma protein. Genes \& Dev. 8: 1759-1771.

Hayday, A.C. 1992 . T cell receptor $\gamma \delta$. In The encylopedia of immunology (ed. I.M. Roitt and P.J. Delves), Vol. 3, pp. 1428-1433. Academic Press, London, UK.

Hayday, A., S.D. Gillies, H. Saito, C. Wood, K. Wiman, W. Hayward, and S. Tonegawa. 1984. Activation of a translocated human c-myc gene by an enhancer in the immunoglobulin heavy chain locus. Nature 307: 334-340.

Kitamura, D., A. Kudo, S. Schaal, W. Muller, F. Melchers, and K. Rajewsky. 1992. A critical role of $\lambda 5$ protein in B cell development. Cell 69: 823-831.

Koff, A., A. Giordano, D. Desai, K. Yamashita, J.W. Harper, S. Elledge, T. Nishimoto, D.O. Morgan, B.R. Franza, and J.M. Roberts. 1992. Formation and activation of a cyclin E-cdk2 complex during the Gl phase of the human cell cycle. Science 257: 1689-1694.

Lin, W.-C. and S. Desiderio. 1993. Regulation of V(D)J recombination activator protein RAG-2 by phosphorylation. Science 260: 953-959.

1995. V/D |J recombination and the cell cycle. Immunol. Today 16:(6) 279-289.

Liu, C.-P., R. Ueda, J. She, J. Sancho, B. Wang, G. Weddell, J. Loring, C. Kurahara, E.C. Dudley, A.C. Hayday, C. Terhorst, and $M$. Huang. 1993. Abnormal T cell development in CD3- $\zeta$ -/- mutant mice and identification of a novel $T$ cell population in the intestine. EMBO J. 12: 4863-4875.

Livak, F., H.T. Petrie, I.N. Crispe, and D.G. Schatz. 1995. In frame TCR $\delta$ gene rearrangements play a critical role in the $\alpha \beta / \gamma \delta \mathrm{T}$ cell lineage decision. Immunity 2: 617-627.
Mallick, C., E.C. Dudley, J.L. Viney, M.J. Owen, and A.C. Hayday. 1993. Rearrangement and diversity of $T$ cell receptor $\beta$ chain genes in thymocytes: A critical role for the $\beta$ chain in development. Cell 73: 513-519.

Mallisen, M., J. Trucy, E. Jouvin-Marche, P.A. Cazenave, R. Sollay, B. Mallisen. 1992. Regulation of TCR alpha and beta gene allelic exclusion during T-cell development. Immunol. Today 13:(8) 315-322.

Marraccino, R.L., E.J. Firpo, and J.M. Roberts. 1992. Activation of the $\mathrm{p} 34 \mathrm{CDC} 2$ protein kinase at the start of $\mathrm{S}$ phase in the human cell cycle. Mol. Biol. Cell 3(4): 389-401.

Mombaerts, P., J. Iacomini, R.S. Johnson, K. Herrup, S. Tonegawa, and V.E. Papaioannou. 1992a. RAG-1-deficient mice have no mature B and T lymphocytes. Cell 68: 869-877.

Mombaerts, P., A.R. Clark, M.A. Rudnicki, J. Iacomini, S. Itohara, J.J. Lafaille, L. Wang, Y. Ichikawa, R. Jaenisch, M.L. Hooper, and S. Tonegawa. 1992b. Mutations in T-cell antigen receptor genes $\alpha$ and $\beta$ block thymocyte development at different stages. Nature 360: 225-231.

Ohtsubo, M. and J.M. Roberts. 1993. Cyclin dependant regulation of Gl in mammalian fibroblasts. Science 259: 19081912.

Padovan, E., G. Casorati, P. Dellabona, S. Meyer, M. Brockhaus, and A. Lanzevecchia. 1993. Expression of two TCR alpha chains: Dual receptor T cells. Science 262: 422-424.

Pearse, M., L. Wu, M. Egerton, A. Wilson, K. Shortman, and R. Scollay. 1989. A murine early thymocyte developmental sequence is marked by transient expression of the interleukin 2 receptor. Proc. Natl. Acad. Sci. 86: 1614-1618.

Penit, C., B. Lucas, and F. Vasseur. 1995. Cell expansion and growth arrest phases during the transition from precursor $\left(\mathrm{CD} 4^{-} 8^{-}\right)$to immature $\left(\mathrm{CD}^{+} 8^{+}\right)$thymocytes in normal and genetically modified mice. I. Immunol. 154: 5103-5113.

Petrie, H.T., P. Hugo, R. Scollay, and K. Shortman. 1990. Lineage relationships and developmental kinetics of immature thymocytes: CD3, CD4, and CD8 acquisition in vivo and in vitro. I. Exp. Med. 172: 1583-1588.

Pines, J. and T. Hunter. 1991. Human cyclins $\mathrm{A}$ and $\mathrm{Bl}$ are differentially located in the cell and undergo cell cycle-dependant nuclear transport. I. Cell Biol. 115: 1-17.

Polyak, K., J. Kato, M.J. Solomon, C.J. Sherr, J. Massague, J.M.

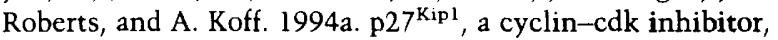
links transforming growth factor $\beta$ and contact inhibition to cell cycle arrest. Genes \& Dev. 8: 9-22.

Polyak, K., M. Lee, H. Erdjument-Bromage, A. Koff, J.M. Roberts, P. Tempst, and J. Massague. 1994b. Cloning of p27 ${ }^{\text {Kipl }}$, a cyclin-dependent kinase inhibitor and a potential mediator of extracellular antimitogenic signals. Cell 78: 59-66.

Pringle, J.R. and L.H. Hartwell. 1981. The Saccharomyces cerevisiae cell cycle. In Molecular biology of the yeast Saccharomyces: Life cycle and inheritance, Vol. 1, pp. 97-142, Cold Spring Harbor Laboratory, Cold Spring Harbor, New York.

Reynisdottir, I., K. Polyak, A. Iavarone, and J. Massague. 1995. $\mathrm{Kip} / \mathrm{Cip}$ and Ink4 Cdk inhibitors cooperate to induce cell cycle arrest in response to TGF- $\beta$. Genes \& Dev. 9: 18311845.

Robey, E. and B.J. Fowlkes. 1994. Selective events in T cell development. Annu. Rev. Immunol. 12: 675-705.

Rothenberg, E. 1992. The development of functionally responsive T cells. $A d v$. Immunol. 51: 85-214.

Saint-Ruf, C., K. Ungewiss, M. Groettrup, L. Bruno, H.J. Fehling, and H. von Boehmer. 1994. Analysis and expression of a cloned pre-T cell receptor gene. Science 266: 1208-1212.

Schlissel, M. and T. Morrow. 1994. Ig heavy chain protein controls B cell development by regulating germ-line transcription and retargeting $V(D) J$ recombination. I. Immunol. 
Hoffman et al.

153: 1645-1657.

Scollay, R. and K. Shortman. 1985. Identification of early stages of $\mathrm{T}$ lymphocyte development in the thymus cortex and medulla. I. Immunol. 134: 3632-3642.

Sherr, C.J. and J.M. Roberts. 1995. Inhibitors of mammalian $\mathrm{G}_{1}$ cyclin-dependant kinases. Genes \& Dev. 9: 1149-1163.

Shinkai, Y., G. Rathbun, K.-P. Lam, E.M. Oltz, V. Stewart, M. Mendelsohn, J. Charron, M. Datta, F. Young, A.M. Stall, and F.W. Alt. 1992. RAG-2-deficient mice lack mature lymphocytes owing to inability to initiate $\mathrm{V}(\mathrm{D}) \mathrm{J}$ rearrangment. Cell 68: $855-867$.

Shinkai, Y., S. Koyasu, K.-I. Nakayama, K.M. Murphy, D.Y. Loh, E.L. Reinherz, and F.W. Alt. 1993. Restoration of T cell development in RAG-2-deficient mice by functional TCR transgenes. Science 259: 822-825.

Siebenlist, U., P. Bressler, and K. Kelly. 1988. Two distinct mechanisms of transcriptional control operate on c-myc during differentiation of HL60 cells. Mol. Cell. Biol. 8: 867-874.

Solomon, M.J., M. Glotzer, T.H. Lee, M. Phillipe, and M.W Kirschner. 1990. Cyclin activation of $\mathrm{p} 34^{\mathrm{cdc} 2}$. Cell 63: 10131024.

Turka, L.A., D.G. Schatz, M.A. Oettinger, J.J.M. Chun, C. Gorka, K. Lee, W.T. McCormack, and C.B. Thompson. 1991. Thymocyte expression of RAG-1 and RAG-2: Termination by $T$ cell receptor cross-linking. Science 253: 778-781.

Uematsu, Y., S. Ryser, Z. Dembic, P. Borgulya, P. Krimpenfort, A. Berns, and H. von Boehmer. 1988. In transgenic mice the introduced functional $\mathrm{T}$ cell receptor $\beta$ gene prevents expres sion of endogenous $\beta$ genes. Cell 52: 831-841.

Wang, L.C., Y.Y. Chen, and N. Rosenberg. 1995. Pre-B-cells transformed by ts Abelson virus rearrange kappa and lambda genes in early G1. Curr. Topics Microbiol. Immunol. 194: 355-361.

Wilson, A., A. D'Amico, T. Ewing, R. Scollay, and K. Shortman. 1988. Subpopulations of early thymocytes. A cross-correlation flow cytometric analysis of adult mouse Ly-2-L3T4$\left(\mathrm{CD} 8^{-} \mathrm{CD} 4^{-}\right)$thymocytes using eight different surface markers. J. Immunol. 140: 1461-1470.

Wilson, A., W. Held, and H.R. MacDonald. 1994. Two waves of recombinase gene expression in developing thymocytes. I. Exp. Med. 179: 1355-1360.

Wiman, K., B. Clarkson, A.C. Hayday, H. Saito, S. Tonegawa, and W.S. Hayward. 1984. Activation of a translocated c-myc gene: role of structural alterations in the upstream region. Proc. Natl. Acad. Sci. 81: 6798-6802.

Wu, L., R. Scollay, M. Egerton, M. Pearse, G. Spangrude, and K. Shortman. 1991. CD4 expressed on earliest T-lineage precursor cells in the adult murine thymus. Nature 346: 71-74. 


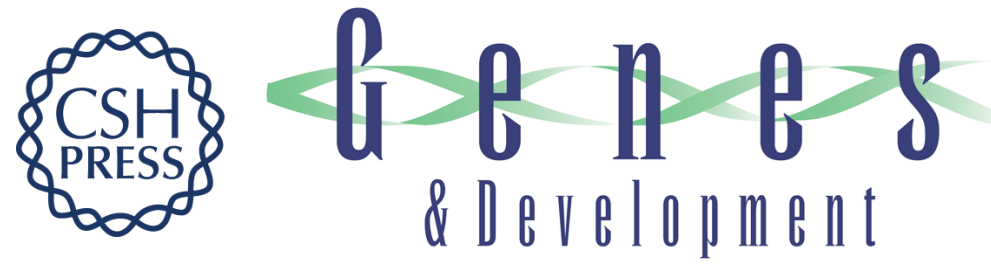

\section{Productive T-cell receptor beta-chain gene rearrangement: coincident regulation of cell cycle and clonality during development in vivo.}

E S Hoffman, L Passoni, T Crompton, et al.

Genes Dev. 1996, 10:

Access the most recent version at doi:10.1101/gad.10.8.948

References This article cites 50 articles, 27 of which can be accessed free at: http://genesdev.cshlp.org/content/10/8/948.full.html\#ref-list-1

License

Email Alerting

Service

Receive free email alerts when new articles cite this article - sign up in the box at the top right corner of the article or click here.

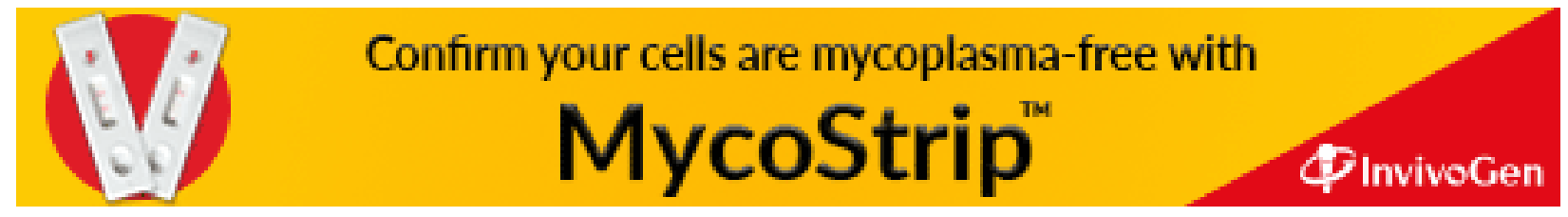

